\title{
Immunotherapeutic Strategies for Brain Tumors
}

\author{
Mitsugu Fujita ${ }^{1}$ and Hideho Okada ${ }^{2}$ \\ ${ }^{1}$ Division of Immunology and Neurosurgery, Aichi Cancer Center Research Institute \\ ${ }^{2}$ Brain Tumor Program, University of Pittsburgh Cancer Institute \\ 1 Japan \\ 2United States of America
}

\section{Introduction}

Cancer immunotherapy is the use of the immune system to reject cancers. The main premise is to harness the patient's immune system to attack the malignant tumor cells. This area of research has made tremendous progresses, and the United States Food and Drug Administration recently approved a vaccine for prostate cancers as the first approval for vaccines against non-viral cancers (Kantoff et al., 2010). However, when it comes to central nervous system (CNS) tumors, while early phase immunotherapy trials showed encouraging outcomes, the immunological microenvironment of the CNS and tumors arising in the CNS is still believed to be suboptimal for sufficient antitumor immune responses to mediate clinically-meaningful changes in situ (Okada, H. et al., 2009; Walker, P. R. et al., 2003). In this chapter, we first discuss recent advances in the CNS and CNS tumor immunology. We address factors that may promote immune escape of gliomas. We also review advances in passive and active immunotherapy strategies for glioma, with an emphasis on lessons learned from recent early phase clinical trials. We also discuss novel immunotherapy strategies that have been recently tested in non-CNS tumors with great potential for application to CNS tumors. We will finally discuss how each of these promising strategies can be combined to achieve clinical benefit for patients with CNS tumors.

\section{Immunology of gliomas}

\subsection{Immunology of CNS}

For many decades, the brain has been considered an immune-privileged site due to the presence of a blood brain barrier (BBB) and the lack of lymphatics (Ransohoff et al., 2003). More recent studies have revealed crucial components involved in the process of leukocyte migration towards the CNS and the mechanisms of neuroinflammatory reactions in the CNS (Ransohoff et al., 2003). This section will focus on three key issues of CNS immunology: 1) factors limiting inflammation in the CNS, 2) antigen-specific immune response in the CNS, and 3) immune cell trafficking towards the CNS. In-depth understanding of these aspects will allow us to gain a framework to improve current treatment strategies harnessing the immune system to treat brain tumors. 


\subsubsection{Factors limiting inflammation in the CNS}

Cells composing the CNS are extremely sensitive to the toxic effects of exogenous substances. Therefore, the CNS and the neurovasculature system therein have evolved specialized mechanisms to control both molecular and cellular migration into and out of the CNS parenchyma and cerebral spinal fluid (CSF). Capillary endothelial cells in the CNS are termed the BBB due to their ability to restrict passive diffusion and maintain low pinocytotic activity, and neuroimmunologists synonymously use the term BBB to describe both the capillary and post capillary vessels, the latter of which is the site of T-cell migration into the brain (Ransohoff et al., 2003). This "barrier" results from the selectivity of the tight junctions (TJs) between endothelial cells in the CNS vessels that restrict the passage of large hydrophilic molecules (i.e. peptides and proteins) and cells (Abbott et al., 2006).

Many extracellular proteins have been studied as TJ proteins: primarily the occludin, claudin, and junctional adhesion molecule (JAM) families. Experimental characterization of each has shown that mice carrying a null mutation in the occludin gene develop normal TJs whereas claudins have been shown to be independently sufficient for TJ formation (Engelhardt, 2008), suggesting the importance of claudins in TJ formation and regulation. Additionally, intravenous injection of monoclonal antibodies blocking JAM into mice inhibits leukocyte accumulation in CSF and brain parenchyma presumably through blocking leukocyte transmigration at the BBB (Engelhardt, 2008).

\subsubsection{Induction of Immune responses to CNS antigens}

The classic paradigm of specific immune activation is achieved through antigen uptake by antigen-presenting cells (APCs), which migrate to the lymph nodes via draining lymphatics where APCs subsequently activate T-cells. In the systemic immune system, dendritic cells (DCs) are considered to be the most potent APCs. In the CNS, a variety of cell populations have been postulated as primary CNS APCs, including vascular endothelial cells, smooth muscle cells, astrocytes, perivascular macrophages, choroid plexus epithelial cells, neurons, and DCs (Dunn et al., 2007). Among them, microglia has been proposed to be the primary resident APCs in the CNS (Aloisi, 2001).

Presentation of CNS antigens can occur through multiple mechanisms (Walker, P. R. et al., 2003): 1) APC uptake antigen within the CNS and migrate to lymph nodes to present antigens; 2) antigen drains to lymph nodes where APCs take them up to present, and 3) cells that express the antigen directly drain to lymph nodes and present their own antigen (direct presentation as opposed to cross presentation by DCs). Indeed, DCs injected in brain tumors have been shown to migrate to the cervical lymph nodes (CLNs) (Dunn et al., 2007). In addition, autoantigens from brain lesions have been shown to drain to CLNs in both primate models of experimental allergic encephalomyelitis and human multiple sclerosis (de Vos et al., 2002). Concurrently, it has been shown that tumor-specific T-cells can be primed in CLNs in murine glioma models (Fujita et al., 2009; Kuwashima et al., 2005; Okada, N. et al., 2005).

\subsubsection{Migration of immune cells towards the CNS}

Lymphocytes traffic to the CNS through the following 4 steps: 1) tethering/rolling, 2) activation, 3) adhesion, and 4) transmigration (Engelhardt, 2008). Interactions between carbohydrates on leukocytes and adhesion molecules (usually selectins) on endothelial cells slow down the leukocytes. Chemokines (e.g. CXCL10) are released from a site of 
inflammation and form a concentration gradient in endothelial membrane and attract responsible leukocytes such as activated T-cells (Fujita et al., 2009; Nishimura et al., 2006). At a reduced velocity, the leukocytes sense chemokines on the endothelial cells, become activated through G-protein signaling, and up-regulate integrins such as very late antigen 4 (VLA-4) (Sasaki et al., 2007; Sasaki et al., 2008a; Sasaki et al., 2008b; Sasaki et al., 2009). Lymphocyte function-associated molecules (LFAs) on lymphocytes allow for a stable interaction to their ligands vascular cell adhesion proteins (VCAMs) and inter-cellular adhesion molecules (ICAMs) on endothelial cells. Finally, with this tight interaction in place, the cells transmigrate into the parenchyma.

\subsection{Immunosuppression by gliomas}

Previously characterized immunological impairments in glioma patients have included low peripheral lymphocyte counts, reduced delayed-type hypersensitivity reactions to recall antigens, and impaired proliferating responses by peripheral blood mononuclear cells (PBMCs). Gliomas are known to achieve these by producing imunosuppressive molecules and inducing immunosuppressive leukocytes.

\subsubsection{Immunosuppressive factors}

\section{Transforming growth factor $\beta$ (TGF- $\beta$ )}

TGF- $\beta$ is the most potent immunosuppressive cytokine; its biological effects are multiple and complex (Gorelik et al., 2002). They include the inhibition of 1) APC maturation 2) antigen presentation of APCs, 3) T-cell activation, and 4) their differentiation towards effector cells. Recent studies have shown that TGF- $\beta$ is up-regulated in glioma cell clones that are resistant to the cytotoxic effects of allogeneic cytotoxic T-cells (CTLs), suggesting the significance of TGF- $\beta$ in glioma immune escape mechanisms (Gomez et al., 2007; Ueda et al., 2009).

\section{Interleukin 10 (IL-10)}

IL-10 is also known to be a strong immunosuppressive cytokine (Moore et al., 2001). Like TGF- $\beta$, this cytokine has pleiotropic effects in immunoregulation and inflammation. It down-regulates the expression of Th1 cytokines, MHC class II antigens, and costimulatory molecules on APCs. The expression levels of IL-10 in glioma tissue correlate with glioma grade as well as a degree of brain invasiveness (Huettner et al., 1997; Nitta et al., 1994).

\section{Prostaglandin $\mathrm{E}_{2}\left(\mathrm{PGE}_{2}\right)$}

$\mathrm{PGE}_{2}$ is a product of arachadonic acid metabolism. It is produced at sites of inflammation or tissue damage where it exerts many effects including the enhancement of vascular permeability. As $\mathrm{PGE}_{2}$ has profound modulatory effects on T-cell activation and gliomas synthesize $\mathrm{PGE}_{2}$, it is associated with the suppressed T-cell function observed in patients with gliomas (Castelli et al., 1989). In addition, we recently demonstrated that $\mathrm{PGE}_{2}$ production from murine gliomas induces accumulation of tumor-associated myeloid cells that promote growth of gliomas (Fujita et al., 2011).

\section{CCL2; macrophage chemoattractive protein 1 (MCP-1)}

CCL2, also known as MCP-1, is a chemokine secreted by a variety of glioma cell lines and expressed in glioblastoma multiforme (GBM) (Desbaillets et al., 1994; Takeshima et al., 1994). In addition to its angiogenetic effects (Salcedo et al., 2000), it is associated with 
recruitment of immunosuppressive leukocytes, such as tumor-associated macrophages and regulatory T cells (Fujita et al., 2010; Fujita et al., 2011; Huang et al., 2007; Jordan et al., 2008).

\section{Fas receptor/ligand}

The Fas receptor is a death receptor on the surface of cells that leads to apoptosis. Malignant gliomas express Fas ligand, which induces apoptotic cell death of adjacent immune cells infiltrating into tumors sites (Walker, P. R. et al., 1997). In addition, Fas receptor expressed on glioma cells induces proinflammatory and angiogenic mediators, which in turn protect and support tumors growth (Shinohara et al., 2000).

\section{B7-homologue 1 (B7-H1); programmed death ligand-1 (PD-L1)}

The B7 family consists of co-stimulatory molecules that positively and negatively regulate immune responses. Among them, B7-H1, also known as PD-L1, exerts immunosuppressive functions when interacting with its receptor PD-1 (Chen, 2004). Glioma cells express B7-H1, which subsequently inhibits T-cell functions by decreasing cytokine production levels (IFN$\gamma$, IL-2, and IL-10) and expression levels of the T-cell activation marker CD69 (Wintterle et al., 2003). Glioma cells often exhibit mutations in a tumor-suppressor gene phosphatase and tensin homolog (PTEN), and loss of functions in PTEN also leads to up-regulation of B7-H1 (Parsa et al., 2007).

\subsubsection{Immunosuppressive leukocytes}

A large number of observations suggest that certain types of immune cells in the tumor micrienvironment (TME) are not innocent bystanders at brain tumor sites, but they actively promote tumor development and progression. Inflammatory cells, primarily macrophage/microglia and regulatory T-cells, may affect these processes via their ability to express a large variety of factors, including immunoregulatory cytokines. These cytokines may be secreted not only by inflammatory cells, but also by the tumor cells and stroma cells, together establishing a network of factors that significantly affects brain tumor.

\section{Macrophages/microglia}

In the CNS, macrophage/microglial cells constitute the first line of cellular defense against a variety of stressors, participating in the regulation of innate and adaptive immune responses (Graeber et al., 2002). Resident microglias are $\mathrm{CD} 11 \mathrm{~b}^{+} / \mathrm{CD} 45_{\mathrm{dim}}$ whereas macrophages are $\mathrm{CD} 11 \mathrm{~b}^{+} / \mathrm{CD} 45^{\text {high }}$. Intratumoral macrophage/microglia density is higher than in normal brain and abundance of microglia correlates with the grade of malignancy (Badie et al., 2000).

In contrast, the defense functions of macrophage/microglia against glioma are compromised in the TME. Although these cells express Toll-like receptors (TLRs), critical components for APCs to mediate innate immune responses and activate adaptive immune responses, those in the TME are unable to activate T-cells properly (Hussain et al., 2006). Consistently, macrophages/microglia release many factors, including extracellular matrix proteases (MMPs) and cytokines, which may directly or indirectly influence tumor migration/invasiveness and proliferation (Watters et al., 2005). In addition, glioma cell migration is stimulated by the presence of macrophage/microglia (Bettinger et al., 2002). Taken together, macrophages/microglias in gliomas promote the invasive phenotype of these tumors.

\section{Regulatory T-cells (Treg)}

The suppressive activity of Tregs has been implicated as an important factor limiting immune-mediated destruction of tumor cells. The presence of $\mathrm{CD}^{+}{ }^{+} \mathrm{FoxP} 3+$ Tregs correlates 
with impairment of T-cell proliferation in peripheral blood specimens in GBM patients (Fecci et al., 2006). Moreover, tumor infiltration by Tregs correlates with tumor grade and prognosis (Heimberger et al., 2008).

$\mathrm{CD}^{+}{ }^{+} \mathrm{FoxP3}^{+}$Tregs in gliomas have been shown to express CD25, CTLA-4, GITR, and CXCR4 at high levels (Grauer et al., 2007). Intratumoral accumulation and activation of $\mathrm{CD}^{+}{ }^{+} \mathrm{FoxP}^{+}$Treg act as a dominant immune escape mechanism of gliomas and underline the importance of controlling tumor-infiltrating Treg in glioma immunotherapy.

\section{Immunotherapy for gliomas}

In this section, we will first discuss molecular targets for gliomas. Then, we will discuss two modalities: adoptive T-cell therapy (passive immunotherapy) and glioma vaccine (active immunotherapy).

\subsection{Target molecules for gliomas}

It is essential to know about potent target molecules for glioma immunotherapy. The following section will discuss selected human glioma-associated antigen (GAA)-derived epitopes that appear to be promising based on relatively restricted expression (compared with the normal brain) as well as well-characterized immunogenicity.

\section{IL-13R $\alpha 2$}

IL-13Ra2 is a membrane glycoprotein that is overexpressed by $>80 \%$ of malignant gliomas but is not expressed in normal brain tissues or other normal organs except for testes (Debinski et al., 1999). Therefore, IL-13R $\alpha 2$ has attracted significant attention as a target for glioma therapy (Kahlon et al., 2004). We recently found that an analogue peptide of natural IL-13R $\alpha 2_{345-353}$, in which the first and ninth amino-acid residues tryptophan and isoleucine have been replaced by valine and alanine, respectively, can elicit a greater CTL response against HLA-A2+ IL-13R $\alpha 2^{+}$glioma cells compared with the natural peptide (IL-13R $\alpha 2_{345-}$ 353:1A9v) (Eguchi et al., 2006).

\section{EphA2}

EphA2 is a tyrosine kinase receptor that plays a role in carcinogenesis (Dodelet et al., 2000). We have reported that EphA2 $883-891$ is expressed on gliomas and able to elicit an HLA-A2restricted CTL response against glioma cell lines (Hatano et al., 2005). Furthermore, EphA2 mRNA overexpression was found to correlate inversely with survival in a panel of 21 GBMs (Liu et al., 2006). These findings support the idea that targeting of EphA2 by immunotherapy may provide a major impact in controlling tumor growth and prolonging patients' survival.

\section{Survivin}

Survivin is an apoptosis inhibitor protein overexpressed in most human cancers including gliomas (Blanc-Brude et al., 2002; Uematsu et al., 2005). Therefore, induction of immune response against Survivin appears to be an attractive strategy. Of interest, high level expression of Survivin was correlated with poor prognosis in patients with grade II or III astrocytomas (Uematsu et al., 2005).

\section{Wilm's tumor 1 (WT1)}

WT1 is a transcription factor oncogene that is overexpressed in various types of leukemia and solid tumor cells (Oka et al., 2002). Inhibition of WT1 in leukemic cell lines led to 
decrease in proliferation and increase in apoptosis of tumor cells (Glienke et al., 2007). Human gliomas also express WT1 at high levels (Izumoto et al., 2008; Rushing et al., 2010; Schittenhelm et al., 2008). These finding imply that elimination of tumor cells that overexpress WT1 may allow efficient control against glioma growth.

\section{Sry-related high mobility group box (SOX)}

SOX is a family of transcriptional cofactors implicated in the control of diverse developmental processes and exhibit highly dynamic expression patterns during development of diverse tissues and cell types, especially during embryogenesis (Wegner, 1999). Indeed, SOX2 (Gangemi et al., 2009), SOX5 (Ueda et al., 2007), SOX6 (Ueda et al., 2004), and SOX11 (Schmitz et al., 2007) are highly expressed in glioma cell lines and a majority of glioma tissues. Their preferential expression in glioma and immunogenicity indicate that SOX proteins are attractive targets for immunotherapy.

\section{Type III variant of the EGFR mutation (EGFRvIII)}

EGFRvIII is present in $30-50 \%$ of patients with GBM. Despite the limited frequency in gliomas, EGFRvIII and IL-13R $\alpha 2$ are expressed most restrictedly in primary glioma tissues compared with normal tissues (Saikali et al., 2007). Therefore, this antigen also appears to be an attractive target for glioma immunotherapy.

\section{Cytomegalovirus (CMV)}

Recent reports have demonstrated the presence of the cytomegalovirus (CMV) proteins as well as CMV mRNA in a majority of human GBMs (Barami, 2010; Cobbs et al., 2002; Lucas et al., 2010; Mitchell et al., 2008; Scheurer et al., 2008). Therefore, CMV in gliomas could serve as an immunotherapeutic target for glioma. In addition, the facilitation of an immune response against viral antigens contrasts with the difficulty of immunization against self antigens. It will be intriguing to introduce the CMV-derived epitope to multiepitope-based vaccine for glioma.

\subsection{Adoptive T-cell therapy (ACT) for gliomas}

ACT involves passive infusion or transfer of autologous CTLs specific for tumor antigens to the host. Although ACT are currently evaluated as experimental therapy for limited types of cancers (Gattinoni et al., 2006; Morgan et al., 2006), this strategy may hold promise as an attractive future immunotherapeutic intervention against gliomas. In particular, based on strong findings that CTLs have the capacity to migrate into brain parenchyma (Ransohoff et al., 2003), the approach has been vastly improved by the use of recent advances in several areas of human T-cell biology including in vitro human T-cell culture and ex vivo genetic manipulation. This section will focus on recent technological advances in ACT as well as a current and future ACT for glioma with an emphasis on recent perspectives from human studies.

\subsubsection{Source of glioma-reactive CTLs}

\section{Peripheral Bloods}

PBMCs from glioma patients can be expanded in vitro through multiple cycles of antigenic stimulation. Subsequently, cells with a monoclonal specificity to the particular GAA will be generated. Although few numbers of GAA-reactive CTLs might be obtained this method may be feasible as, this strategy has demonstrated favorable anti-tumor responses in cancer patients (Gattinoni et al., 2006). 


\section{Glioma tissues}

Another important source of the GAA-specific CTLs is a glioma tissue itself. A tumor nodule contains tumor-reactive CTLs that can be first polyclonally expanded ex vivo in the presence of IL-2 and later selected for antigen specificity (Rosenberg, 2008). These CTLs derived from tumor nodules have been used for ACT in melanoma patients (Dreno et al., 2002; Dudley et al., 2005).

\subsubsection{Manipulation of glioma-reactive CTLs ex vivo}

\section{Choice of T-cell subtypes}

In general, an effector T-cell subset $\left(\mathrm{T}_{\mathrm{E}}\right)$ is predominantly enriched during ex vivo expansion for ACT. $\mathrm{T}_{\mathrm{E}}$ are generally considered to be terminally differentiated CTLs that have the highest cytotoxic capacity but lack appreciable proliferating capacity (Wherry et al., 2003). These cells would not be able to establish a long-term persisting population of tumorspecific CTLs. There is a significant association between clinically favorable responses and the persistence of ex vivo expanded melanoma-specific CTL clones after infusion (Robbins et al., 2004). Therefore, efforts have been made to generate long-term persisting CTLs. In contrast to the $\mathrm{T}_{\mathrm{E}}$ subset, memory cells have enhanced proliferative potential and survival, and the potential to provide more robust and enduring protectin aganist tumors (Perret et al., 2008). In particular, recent studies have highlighted the potential of central memory Tcells $\left(\mathrm{T}_{\mathrm{CM}}\right.$ ) as a source of $\mathrm{T}_{\mathrm{E}}$ for ACT (Wang et al., 2011; Yang et al., 2011). Yang et al. have shown that a large parcentage of in vitro generated antitumor CTLs mimick a $\mathrm{T}_{\mathrm{CM}}$-like phenotype and function (Yang et al., 2011). In addition, Wang et al. have demonstrated that $\mathrm{T}_{\mathrm{CM}}$ are less prone to apoptosis and able to establish a persistent reservoir of functional Tcells in mice (Wang et al., 2011). Furthermore, recent studies with human T-cell subsets have revealed that naïve $\mathrm{CD} 8^{+}$cells were not only the most abundant subset but also the population most capable of in vitro expansion and T-cell receptor (TCR) transgene expression. Despite increased expansion, naïve-derived cells displayed minimal effector differentiation, a quality associated with greater efficacy after cell infusion (Hinrichs et al., 2011).

\section{Cloning of high-avidity T-cell receptors (TCRs)}

Since the majority of GAAs are poorly immunogenic to raise CTLs that possess TCRs with low avidity, a number of modification have been made for ACT. One of attempts is to systematically search tumor-specific CD8 ${ }^{+} \mathrm{T}$-cells for clone(s) with higher TCR avidity, clone TCRa and $\beta$ genes, and exogenously induce the high-avidity TCR exogenously in bulk CD8+ T-cells. Li et al. used phage display to search for a high-avidity TCR against an HLA-A0201restricted epitope in a NY-ESO-1 antigen ( $\mathrm{Li}$ et al., 2005). Moreover, ACT using high-avidity TCR transgenic T-cells have been shown to sustain in blood circulation at high levels engineered cells were observed at 1 year after infusion in 2 of 15 patients who both demonstrated objective regression of metastatic melanoma lesions (Morgan et al., 2006). These data suggest the therapeutic potential of genetically engineered high-avidity TCR clones for glioma immunotherapy.

\section{Establishment of chimeric antigen receptors (CARs)}

An interesting alternative to expression of high-avidity TCRs on T-cells is to express a chimeric molecule that has antigen-binding domains of a monoclonal antibody fused with a signal transduction domain of CD3 (Gross et al., 1989), namely chimeric antigen receptors 
(CAR). A significant advantage of CARs over TCRs is that the antigen recognition is not restricted by expression of certain MHC class I molecules. Recently, CARs have been used to treat a number of cancers (Cartellieri et al., 2010). CAR-based approaches are currently being developed for gliomas as well (Kahlon et al., 2004; Ohno et al., 2010).

\subsubsection{Current attempts of ACT for gliomas}

There have been a number of clinical trials for malignant gliomas using ACT (Table1) (Vauleon et al., 2010). Among them, three Phase I trials (Holladay et al., 1996; Plautz et al., 1998; Wood et al., 2000) and two pilot studies (Plautz et al., 2000; Sloan et al., 2000) used CTLs obtained from lymph nodes or PBMCs after intradermal vaccination. Holladay et al. first conducted an ACT-based Phase I clinical trial and reported disease-free survival $\geq 8$ months in 7 of 15 patients (Holladay et al., 1996). Later, Wood et al. demonstrated a correlation between clinical response and the predominance of $\mathrm{CD}^{+} \mathrm{T}$-cells to $\mathrm{CD} 4^{+}$cells in the injected cells (Wood et al., 2000). In addition, DTH response to autologous tumors was shown to correlate with clinical response (Sloan et al., 2000; Wood et al., 2000). However, CTLs used in these studies were not specific for GAAs. Therefore, it is necessary to generate a library of human CTL clones against GAAs using advanced techniques described above. With such refinement of ex vivo T-cell manipulation, ACT may become a mainstream therapeutic intervention for malignant gliomas.

\begin{tabular}{|c|c|c|c|c|}
\hline Study & $\begin{array}{c}\text { Type of } \\
\text { trials }\end{array}$ & Patients & $\begin{array}{l}\text { Immune } \\
\text { responses }\end{array}$ & $\begin{array}{l}\text { Clinical } \\
\text { responses }\end{array}$ \\
\hline $\begin{array}{l}\text { Holladay et al., } \\
1996\end{array}$ & Phase I & $\begin{array}{l}\mathrm{N}=15 \\
\text { recurrent HGG } \\
12 \mathrm{GBM}, 3 \mathrm{AA}\end{array}$ & DTH $(15 / 15)$ & $\begin{array}{c}\text { No PR or SD } \\
\text { Median FPS: } \geq 8 \text { mo }\end{array}$ \\
\hline $\begin{array}{c}\text { Plautz et al., } \\
\text { 1998) }\end{array}$ & Phase I & $\begin{array}{l}\mathrm{N}=10 \\
\text { recurrent HGG } \\
9 \mathrm{GBM}, 1 \mathrm{AA}\end{array}$ & & $\begin{array}{c}3 \text { PR } \\
\text { Median FPS: > } 12 \text { mo }\end{array}$ \\
\hline $\begin{array}{l}\text { Plautz et al., } \\
2000\end{array}$ & $\begin{array}{l}\text { Pilot } \\
\text { study }\end{array}$ & $\begin{array}{c}\mathrm{N}=9 \\
\text { recurrent HGG } \\
6 \mathrm{GBM}, 3 \mathrm{Gr} 3\end{array}$ & DTH $(9 / 9)$ & 3 PR \\
\hline $\begin{array}{l}\text { Wood et al., } \\
2000\end{array}$ & Phase I & $\begin{array}{c}\mathrm{N}=12 \\
\text { newly diagnosed } \\
\text { glioma } \\
6 \mathrm{GBM}, 2 \mathrm{Gr} 2,4 \mathrm{Gr} 3\end{array}$ & DTH (12/12) & $\begin{array}{l}4 \mathrm{PR}, 2 \mathrm{SD} \\
\text { Correlation between clinical } \\
\text { response and CD } 4 / \mathrm{CD} 8 \\
\text { composition of infused cells }\end{array}$ \\
\hline $\begin{array}{l}\text { Sloan et al., } \\
2000\end{array}$ & $\begin{array}{l}\text { Pilot } \\
\text { study }\end{array}$ & $\begin{array}{l}\mathrm{N}=19 \\
\text { recurrent HGG } \\
16 \mathrm{GBM}, 2 \mathrm{AA}, \\
1 \text { gliosarcoma }\end{array}$ & DTH (17/19) & $\begin{array}{l}\text { 1 CR, } 7 \text { PR, } 9 \text { SD } \\
\text { Median OS : } 12 \text { mo } \\
\text { Correlation between survival } \\
\text { and DTH response }\end{array}$ \\
\hline
\end{tabular}

*Abbreviations used in this table. AA: anaplastic astrocytoma; CR: complete response; DTH: delayedtype hypersensitivity; GBM: gliobrastoma; Gr2: WHO grade II glioma; Gr3: WHO grade III glioma; HGG: high-grade glioma; mo: month(s); OS: overall survival; PFS: progression-free survival; PR: partial response; $\mathrm{SD}$ : stable disease.

Table 1. ACT-based clinical trials for glioma 


\subsection{Glioma vaccines}

In addition to the ACT strategy described above, we will discuss glioma vaccine strategies in this section. They include 1) whole glioma cell vaccines, 2) peptide-based vaccines targeting glioma-associated antigens, and 3) DC vaccines.

\subsubsection{Whole glioma cell vaccines}

Initial vaccination strategies for gliomas consisted of subcutaneous inoculations of irradiated, autologous (Wikstrand et al., 1980) or allogeneic (Zhang et al., 2007) glioma cells. This type of vaccine has the advantage of providing a panel of multiple potential GAAs that are naturally expressed by glioma cells. Especially, autologous glioma cells should allow immunizations against the most relevant GAAs expressed in the patient's tumor (i.e. tailored medicine). Potential downsides of this approach, however, include: 1) cumbersome procedures and quality control $(\mathrm{QC})$ /quality assurance $(\mathrm{QA})$ issues associated with large scale cultures of autologous glioma cells and 2) theoretical risks of autoimmune encephalomyelitis (Wikstrand et al., 1980). Nevertheless, this type of vaccine strategy has been carefully examined (Table 2). Schneider et al. (Schneider et al., 2001) and Steiner et al.(Steiner et al., 2004) reported pilot clinical trials using autologous glioma cells modified

\begin{tabular}{|c|c|c|c|c|c|}
\hline Study & $\begin{array}{c}\text { Type of } \\
\text { trials }\end{array}$ & Patients & $\begin{array}{l}\text { Tumor cell } \\
\text { modification }\end{array}$ & $\begin{array}{l}\text { Immune } \\
\text { responses }\end{array}$ & $\begin{array}{l}\text { Clinical } \\
\text { responses }\end{array}$ \\
\hline $\begin{array}{l}\text { Schneider et } \\
\text { al., } 2001\end{array}$ & $\begin{array}{l}\text { Pilot } \\
\text { study }\end{array}$ & $\begin{array}{c}\mathrm{N}=11 \\
\text { newly diagnosed } \\
\text { GBM }\end{array}$ & $\begin{array}{l}\text { infected with } \\
\text { NDV, } \\
\text { inactivated with } \\
\text { cisplatinum }\end{array}$ & $\begin{array}{c}\text { DTH }(11 / 11) \\
\text { T cell infiltrate } \\
(4 / 4)\end{array}$ & $\begin{array}{c}\text { No survival } \\
\text { benefit }\end{array}$ \\
\hline $\begin{array}{l}\text { Andrews et } \\
\text { al., } 2001\end{array}$ & $\begin{array}{l}\text { Pilot } \\
\text { study }\end{array}$ & $\begin{array}{c}\mathrm{N}=12 \\
8 \mathrm{GBM}, 4 \mathrm{AA}\end{array}$ & IGF-RA/AS ODN & $\begin{array}{l}\text { T cell infiltrate } \\
(4 / 9)\end{array}$ & $2 \mathrm{CR}, 4 \mathrm{PR}, 2 \mathrm{SD}$ \\
\hline $\begin{array}{l}\text { Steiner et al., } \\
2004\end{array}$ & $\begin{array}{l}\text { Pilot } \\
\text { study }\end{array}$ & $\mathrm{N}=23 \mathrm{GBM}$ & $\begin{array}{l}\text { infected with } \\
\text { NDV }\end{array}$ & $\begin{array}{c}\text { DTH }(15 / 15) \\
\text { ELISPOT }(3 / 3) \\
\text { T cell infiltrate } \\
(6 / 7)\end{array}$ & $\begin{array}{c}1 \mathrm{CR} \\
\text { Median OS: } \\
100 \mathrm{wks}\end{array}$ \\
\hline $\begin{array}{l}\text { Parney et al., } \\
2006\end{array}$ & $\begin{array}{l}\text { Pilot } \\
\text { study }\end{array}$ & $\begin{array}{c}\mathrm{N}=6 \\
3 \text { recurrent GBM } \\
3 \text { melanoma }\end{array}$ & $\begin{array}{l}\text { transduced with } \\
\text { B7-2 and GM-CSF }\end{array}$ & No CTL activity & $\begin{array}{l}\text { Longer PFS } \\
(3 / 6 \mathrm{GBM})\end{array}$ \\
\hline $\begin{array}{c}\text { Ishikawa et al., } \\
2007\end{array}$ & $\begin{array}{l}\text { Pilot } \\
\text { study }\end{array}$ & $\begin{array}{c}\mathrm{N}=12 \\
8 \text { newly diagnosed } \\
\text { GBM, } 4 \text { recurrent } \\
\text { GBM }\end{array}$ & formalin-fixed & DTH $(9 / 12)$ & $\begin{array}{l}1 \mathrm{CR}, 1 \mathrm{PR}, \\
2 \mathrm{MR} \\
\text { Median OS: } \\
10.7 \mathrm{mo}\end{array}$ \\
\hline $\begin{array}{c}\text { Clavreul et al., } \\
2010\end{array}$ & Phase I & $\begin{array}{c}\mathrm{N}=5 \\
\text { recurrent HGG } \\
4 \mathrm{GBM}, 1 \mathrm{AOA}\end{array}$ & irradiated & DTH (2/5) & $3 \mathrm{SD}$ \\
\hline
\end{tabular}

*Abbreviations used in this table. AOA: anaplastic oligoastrocytoma; CTL: cytotoxic T-cells; ELISPOT: enzyme-linked immunosorbent spot; IGF-RA/AS ODN: insulin-like growth factoro type I receptor antisence oligodeoxynucleotide; MR: minor response; NDV: Newcastle-Disease-Virus; wk: week(s).

Table 2. Autologous whole glioma cell vaccine trials. 
with Newcastle-Disease-Virus (NDV), which is known to serve as an vaccine adjuvant and therefore to improve the efficacy of glioma vaccines. Recently, Ishikawa et al. reported a Phase I clinical trial using formalin-fixed glioma tissues as a source of antigens (Ishikawa et al., 2007). The advantage of this strategy is that formalin fixation preserves the specific antigenicity of glioma cells. These studies reported no major adverse events.

\subsubsection{Peptide-based vaccines targeting glioma-associated antigens}

In vaccines using synthetic peptides for shared GAA-epitopes, advantages and disadvantages are distinct from those in whole glioma cell approaches. While synthetic GAA peptide-based vaccines may not adequately target antigens in each patient's tumor, these vaccines have less concern for autoimmunity and provide "off the shelf" feasibility. Indeed, a wide range of peptide-based vaccines have been clinically evaluated (Table 3). Yajima et al. reported a phase I study of peptide-based vaccinations in patients with recurrent malignant gliomas (Yajima et al., 2005). In this study, prior to the first vaccine, each patient's PBMCs were evaluated in vitro for cellular and humoral responses against a panel of antigens, and peptides that induced positive response were used for vaccinations. The regimen was well tolerated and resulted in an 89-week median survival of treated patients. However, there is little evidence that the antigens used in this study are expressed in gliomas at high levels. More recently, as the extension of the approach, Terasaki et al. reported a Phase I trial using 14 HLA-A24-binding peptides (Terasaki et al., 2011). They evaluated immune responses with dose escalation of peptides and defined $3 \mathrm{mg} /$ peptide as the Phase II-recommended dose. Izumoto et al. reported a Phase II clinical trial using a single WT1 peptide (Izumoto et al., 2008). In this study, they reported a median progressionfree survival (PFS) of 20 weeks and a possible association between the WT1 expression levels and clinical responses. When single or oligo antigens are selected and targeted by vaccines, it also seems necessary to harness the concepts of epitope spreading to address the problems of tumor immune escape, while avoiding the augmentation of deleterious CNS autoimmune responses (Vanderlugt et al., 2002). Sampson et al. recently reported a Phase II study targeting the EGFRvIII epitope in newly diagnosed GBM patients who received gross total resection (Sampson et al., 2010). They reported a median PFS of 14.2 months and a median overall survival (OS) of 26.0 months. In addition, they identified that the development of specific antibody or delayed-type hypersensitivity responses to EGFRvIII significantly correlated with the OS.

\begin{tabular}{|c|c|c|c|c|c|}
\hline Study & $\begin{array}{c}\text { Type of } \\
\text { trials }\end{array}$ & Patients & Peptide(s) & $\begin{array}{l}\text { Immune } \\
\text { responses }\end{array}$ & $\begin{array}{l}\text { Clinical } \\
\text { responses }\end{array}$ \\
\hline $\begin{array}{l}\text { Yajima et al., } \\
2005\end{array}$ & Phase I & $\begin{array}{c}\mathrm{N}=25 \\
17 \mathrm{GBM}, 8 \mathrm{Gr} 3\end{array}$ & multiple & $\begin{array}{l}\text { DTH }(11 / 21) \\
\text { CTL activity } \\
(14 / 21)\end{array}$ & $\begin{array}{c}5 \text { PR, 8 SD } \\
\text { Median OS: } 89 \text { wks }\end{array}$ \\
\hline $\begin{array}{c}\text { Izumoto et al., } \\
2008 \\
\end{array}$ & Phase II & $\begin{array}{c}\mathrm{N}=21 \\
\text { recurrent GBM }\end{array}$ & WT1 & DTH $(21 / 21)$ & $\begin{array}{c}2 \text { PR, } 10 \text { SD } \\
\text { Median PFS: } 20 \mathrm{wks} \\
\end{array}$ \\
\hline $\begin{array}{c}\text { Sampson et al., } \\
2010\end{array}$ & Phase II & $\begin{array}{c}\mathrm{N}=18 \\
\text { newly diagnosed } \\
\text { GBM }\end{array}$ & EGFRvIII & $\begin{array}{l}\text { DTH }(5 / 9) \\
\text { CTL activity } \\
(10 / 12)\end{array}$ & $\begin{array}{c}\text { Median PFS: } \\
\text { 14.2 months } \\
\text { Median OS: } 26.0 \text { mo }\end{array}$ \\
\hline $\begin{array}{c}\text { Terasaki et al., } \\
2011\end{array}$ & Phase I & $\begin{array}{c}\mathrm{N}=12 \\
\text { recurrent } \mathrm{GBM}\end{array}$ & multiple & $\begin{array}{l}\text { CTL activity } \\
(8 / 12)\end{array}$ & $\begin{array}{c}1 \text { PR, 7 SD } \\
\text { Median PFS: } 2.3 \mathrm{mo} \\
\text { Median OS: } 18.9 \mathrm{mo}\end{array}$ \\
\hline
\end{tabular}

Table 3. Peptide-based vaccine trials for glioma. 


\subsubsection{DC vaccines}

DCs are the most potent antigen-presenting cells, driving the activation of T-cells in response to invading microorganisms (Banchereau et al., 2000). The availability to culture DCs from human peripheral blood monocytes has generated significant interest in using DCs in novel cancer vaccination strategies (Banchereau et al., 2000).

To induce tumor-specific immune reaction via DCs, antigen elusion from tumor cells has been performed (Table 4). Yu et al. reported a Phase I trial of vaccinations using DCs pulsed with peptides eluted from autologous glioma cells (Yu et al., 2001). Later, Liau et al. also reported a Phase I trial in patients with newly diagnosed GBM using DCs pulsed with acideluted glioma peptides (Liau et al., 2005). In this study, the authors reported the median OS of 23.4 months and that the benefit of the vaccine treatment was more evident in the subgroup of patients with slowly-progressing tumors and in those with tumors expressing low levels of TGF- $\beta 2$.

\begin{tabular}{|c|c|c|c|c|}
\hline Study & $\begin{array}{c}\text { Type of } \\
\text { trials }\end{array}$ & Patients & $\begin{array}{l}\text { Immune } \\
\text { responses }\end{array}$ & $\begin{array}{l}\text { Clinical } \\
\text { responses }\end{array}$ \\
\hline $\begin{array}{l}\text { Yu et al., } \\
2001\end{array}$ & Phase I & $\begin{array}{c}\mathrm{N}=9 \\
\text { newly diagnosed } \\
\text { HGG } \\
7 \text { GBM, } 2 \text { AA }\end{array}$ & $\begin{array}{c}\text { CTL activity }(4 / 7) \\
\text { T cell infiltrate }(2 / 4)\end{array}$ & Median OS: 455 d \\
\hline $\begin{array}{l}\text { Wheeler et al., } \\
\qquad 2004\end{array}$ & Phase I/II & $\begin{array}{c}\mathrm{N}=25 \\
\text { newly diagnosed } \\
\text { GBM }\end{array}$ & CTL activity $(8 / 24)$ & 3 PR \\
\hline $\begin{array}{l}\text { Liau et al., } \\
\quad 2005\end{array}$ & Phase I & $\begin{array}{c}\mathrm{N}=12 \mathrm{GBM} \\
5 \text { recurrent } \\
7 \text { newly diagnosed }\end{array}$ & $\begin{array}{l}\text { CTL activity }(6 / 12) \\
\mathrm{T} \text { cell infiltrate }(4 / 8)\end{array}$ & $\begin{array}{c}1 \text { PR } \\
\text { Median OS: } 23.4 \text { mo }\end{array}$ \\
\hline
\end{tabular}

Table 4. DC-based vaccine trials using acid-eluted peptides.

However, pulsing DCs with eluted peptides requires a large culture of autologous glioma cells and time-consuming procedures, for which QC/QA is not always feasible. To overcome this issue, glioma cell lysate has been used to pulse DCs in a number of trials (Table 5). Yamanaka et al. reported a Phase I/II study using DC pulsed with glioma lysate. Patients received either DCs matured with OK-432 or DCs without OK-432-mediated maturation (Yamanaka et al., 2003; Yamanaka et al., 2005). GBM patients receiving mature DCs had longer survival than those receiving DCs without OK-432-mediated maturation. Furthermore, patients receiving both intratumoral and intradermal DC administrations demonstrated longer overall survival than those with intradermal administrations alone (Yamanaka et al., 2005). Wheeler et al. reported another Phase II clinical trial with lysatepulsed DCs (Wheeler et al., 2008). IFN- $\gamma$ production levels from post-vaccine PBMC correlated significantly with patients' survival and time to progression. Prins et al. recently reported a Phase I clinical trial in glioma patients using lysate-pulsed DCs (Prins et al., 2011). Interestingly, their gene expression profiling in the participants' GBM tissues demonstrated that the mesenchymal gene expression profile may represent a population of patients with favorable responses to their vaccines. 


\begin{tabular}{|c|c|c|c|c|}
\hline Study & $\begin{array}{c}\text { Type of } \\
\text { trials }\end{array}$ & Patients & $\begin{array}{l}\text { Immune } \\
\text { responses }\end{array}$ & $\begin{array}{l}\text { Clinical } \\
\text { responses }\end{array}$ \\
\hline $\begin{array}{l}\text { Yamanaka } \\
\text { et al., } 2003\end{array}$ & Phase I/II & $\begin{array}{c}\mathrm{N}=10 \\
7 \mathrm{GBM}, \\
3 \text { recurrent Gr3 }\end{array}$ & $\begin{array}{c}\text { DTH }(3 / 6) \\
\text { ELISPOT }(2 / 5) \\
\text { T cell infiltrate }(2 / 2)\end{array}$ & $\begin{array}{c}2 \text { MR, } 4 \text { SD } \\
\text { Median OS: > } 200 \\
\text { wks }\end{array}$ \\
\hline $\begin{array}{l}\text { Yu et al., } \\
2004\end{array}$ & Phase I & $\begin{array}{c}\mathrm{N}=14 \\
1 \mathrm{GBM}, 1 \mathrm{AA}, \\
9 \text { recurrent GBM, } \\
3 \text { recurrent AA }\end{array}$ & $\begin{array}{c}\text { CTL activity }(4 / 9) \\
\text { T cell infiltrate }(3 / 6)\end{array}$ & Median OS: 133 wks \\
\hline $\begin{array}{l}\text { Rutkowski } \\
\text { et al., } 2004\end{array}$ & Phase I & $\begin{array}{c}\mathrm{N}=12 \\
\text { recurrent HGG } \\
11 \mathrm{GBM}, 1 \text { others }\end{array}$ & DTH $(7 / 8)$ & $\begin{array}{c}2 \mathrm{CR}, 1 \text { PR, } 1 \mathrm{SD} \\
\text { Median OS: } 10.5 \mathrm{mo}\end{array}$ \\
\hline $\begin{array}{l}\text { Yamanaka } \\
\text { et al., } 2005\end{array}$ & Phase I/II & $\begin{array}{c}\mathrm{N}=24 \\
\text { recurrent } \mathrm{HGG} \\
18 \mathrm{GBM}, 6 \mathrm{Gr} 3\end{array}$ & $\begin{array}{c}\text { DTH }(8 / 17) \\
\text { ELISPOT }(7 / 16)\end{array}$ & $\begin{array}{l}\text { 1PR, 3MR, } 10 \mathrm{SD} \\
\text { Median OS: } 480 \mathrm{~d} \\
\text { Longer survival } \\
\text { if DC maturation or } \\
\text { IC injection }\end{array}$ \\
\hline $\begin{array}{l}\text { Okada, H. } \\
\text { et al., } 2007\end{array}$ & Phase I & $\begin{array}{c}\mathrm{N}=5 \\
\text { newly diagnosed } \\
\text { GBM }\end{array}$ & No response & No response \\
\hline $\begin{array}{l}\text { Wheeler et al., } \\
2008\end{array}$ & Phase II & $\begin{array}{c}\mathrm{N}=34 \text { GBM } \\
23 \text { recurrent } \\
11 \text { newly diagnosed }\end{array}$ & ELISPOT $(17 / 34)$ & $\begin{array}{c}3 \mathrm{CR}, 1 \mathrm{PR} \\
\text { Median OS: } 642 \mathrm{~d} \\
\text { Correlation between } \\
\text { survival and IFN- } \gamma \\
\quad \text { production }\end{array}$ \\
\hline $\begin{array}{c}\text { De } \\
\text { Vleeschouwer } \\
\text { et al., } 2004\end{array}$ & Phase I/II & $\begin{array}{c}\mathrm{N}=56 \\
\text { recurrent GBM }\end{array}$ & DTH (11/ 23) & Median OS: $9.6 \mathrm{mo}$ \\
\hline $\begin{array}{l}\text { Walker, D. G. } \\
\text { et al., } 2008\end{array}$ & Phase I & $\begin{array}{c}\mathrm{N}=13 \\
9 \mathrm{GBM}, 4 \mathrm{AA}\end{array}$ & T cell infiltrate $(3 / 3)$ & $2 \mathrm{CR}, 3 \mathrm{PR}$ \\
\hline $\begin{array}{l}\text { Ardon et al., } \\
2010\end{array}$ & Phase I/II & $\begin{array}{c}\mathrm{N}=8 \\
\text { newly diagnosed } \\
\text { GBM }\end{array}$ & $\begin{array}{c}\text { DTH }(2 / 5) \\
\text { ELISPOT }(5 / 8)\end{array}$ & Median OS: 24 mo \\
\hline $\begin{array}{l}\text { Prins et al., } \\
2011\end{array}$ & Phase I & $\begin{array}{c}\mathrm{N}=23 \mathrm{GBM} \\
8 \text { recurrent } \\
15 \text { newly diagnosed }\end{array}$ & $\begin{array}{l}\text { increase in systemic } \\
\text { TNF- } \alpha \text { and IL-6 }\end{array}$ & $\begin{array}{l}\text { Median OS: } 31.4 \text { mo } \\
\text { Better imune response } \\
\text { if mesenchymal gene } \\
\text { expression presents }\end{array}$ \\
\hline
\end{tabular}

Table 5. DC-based vaccine trials using autologous tumor cell lysates.

While these studies demonstrate early success of DC-based vaccines in glioma patients, based on our preclinical data demonstrating that type-1 CTLs are capable of mediating effective anti-CNS tumor immunity (Fujita et al., 2008; Nishimura et al., 2006), we recently completed a Phase I/II study of vaccines evaluating safety and immunological activities of vaccines using $\alpha$-type-1-polarized DCs $(\alpha \mathrm{DC} 1)$ that are able to produce high levels of IL-12 and induce long-lived type-1 T-cell responses (Okada, H. et al., 2011). In this study, patients with recurrent malignant glioma received intra-lymphnodal injection of aDC1 loaded with synthetic peptides for GAA epitopes and administration of polyinosinic-polycytidylic acid 
[poly(I:C)] stabilized by lysine and carboxymethylcellulose (poly-ICLC) in HLA-A2+ patients with recurrent malignant gliomas. GAAs for these peptides are EphA2, IL-13R-a2, YKL-40, and gp100. The regimen was well-tolerated and induced positive immune responses against at least one of the vaccination-targeted GAAs in peripheral blood mononuclear cells in $58 \%$ of patients. Peripheral blood samples demonstrated significant up-regulation of type 1 cytokines and chemokines, including interferon- $\alpha$ and CXCL10. For at least 12 months, nine patients achieved progression-free status. One patient with recurrent GBM demonstrated a sustained complete response. IL-12 production levels by aDC1 positively correlated with time to progression. These data support safety, immunogenicity, and preliminary clinical activity of poly-ICLC-boosted aDC1-based vaccines and warrant further development of this approach. Although these Phase I/II studies demonstrate preliminary clinical efficacy, the ultimate judgment for clinical activity has to be made by rigorous evaluation in randomized studies.

\begin{tabular}{|c|c|c|c|c|c|}
\hline Study & $\begin{array}{l}\text { Type of } \\
\text { trials }\end{array}$ & Patients & $\begin{array}{l}\text { Antigen } \\
\text { Source }\end{array}$ & $\begin{array}{l}\text { Immune } \\
\text { responses }\end{array}$ & $\begin{array}{l}\text { Clinical } \\
\text { responses }\end{array}$ \\
\hline $\begin{array}{l}\text { Kikuchi et al., } \\
2001\end{array}$ & Phase I & $\begin{array}{c}\mathrm{N}=8 \\
5 \mathrm{GBM}, 2 \mathrm{AA}, 1 \mathrm{AO}\end{array}$ & $\begin{array}{c}\text { Fused } \\
\text { tumor cells }\end{array}$ & ELISPOT $(6 / 6)$ & $1 \mathrm{MR}, 6 \mathrm{SD}$ \\
\hline $\begin{array}{c}\text { Caruso et al., } \\
2004\end{array}$ & Phase I & $\begin{array}{c}\mathrm{N}=7 \\
\text { recurrent tumors } \\
2 \mathrm{GBM}, 1 \mathrm{AA}, 4 \\
\text { others }\end{array}$ & tumor RNA & No PBMC respnse & $1 \mathrm{PR}, 4 \mathrm{SD}$ \\
\hline $\begin{array}{l}\text { Kikuchi et al., } \\
2004\end{array}$ & Phase I & $\begin{array}{c}\mathrm{N}=15 \\
\text { recurrent HGG } \\
6 \mathrm{GBM}, 7 \mathrm{AA}, 2 \mathrm{OAA}\end{array}$ & $\begin{array}{c}\text { Fused } \\
\text { tumor cells }\end{array}$ & $\begin{array}{c}\text { DTH }(15 / 15) \\
\text { CTL activity }(2 / 8)\end{array}$ & $\begin{array}{l}4 \mathrm{PR}, 2 \mathrm{SD}, \\
1 \mathrm{MR}\end{array}$ \\
\hline $\begin{array}{l}\text { Sampson } \\
\text { et al., } 2009\end{array}$ & Phase I & $\begin{array}{c}\mathrm{N}=12 \\
\text { newly diagnosed } \\
\text { GBM }\end{array}$ & EGFRvIII & $\begin{array}{c}\text { DTH }(5 / 9) \\
\text { CTL activity } \\
(10 / 12)\end{array}$ & $\begin{array}{c}\text { Median OS: } \\
22.8 \mathrm{mo}\end{array}$ \\
\hline $\begin{array}{l}\text { Okada, H. } \\
\text { et al., } 2011\end{array}$ & $\begin{array}{l}\text { Phase } \\
\text { I/II }\end{array}$ & $\begin{array}{c}\mathrm{N}=22 \\
13 \mathrm{GBM}, 5 \mathrm{AA}, \\
3 \mathrm{AO}, 1 \mathrm{AOA}\end{array}$ & $\begin{array}{l}\text { EphA2, } \\
\text { IL-13R-a2, } \\
\text { YKL-40, } \\
\text { gp100 }\end{array}$ & $\begin{array}{l}\text { ELISPOT }(10 / 22) \\
\text { increase in } \\
\text { systemic Th1 } \\
\text { cytokines }\end{array}$ & $\begin{array}{c}\text { Median PFS: } \\
4 \text { mo (GBM) } \\
13 \text { mo (AG) } \\
\text { Correlation } \\
\text { between } \\
\text { survival and } \\
\text { DC-derived } \\
\text { IL-12 levels }\end{array}$ \\
\hline
\end{tabular}

Table 6. Other DC-based vaccine trials for glioma.

\section{Conclusion}

We reviewed recent progress in the field of brain and brain tumor immunology. We also reported recent progress and current challenges in immunotherapeutic strategies for brain tumors. It is clear that the CNS and gliomas are equipped with numerous and layered immunosuppressive and immune escape mechanisms, perhaps including ones that we have not yet identified. These discoveries, however, allow us to develop strategies to overcome each of these mechanisms. 
Remaining unique challenges against gliomas include relative difficulties in obtaining tumor tissues following immunotherapeutic treatments. Unlike other cancers, intracranial glioma tissues are not readily accessible following vaccine treatment. Designing neo-adjuvant settings with vaccines is not always feasible because recurrent malignant gliomas, for which surgical resection is clinically indicated, typically do not allow us to wait for weeks before surgery and often require treatment with high dose corticosteroids.

As reviewed in this article, the concept of immunotherapy has a diverse scope of strategies and target molecules. Extensive review of each field in this article has led us to identify the challenge for each strategy. Such challenges, however, may be overcome by appropriate combinations with other strategies. For example, ACT strategies may need to be combined with appropriate adjuvants and/or vaccinations to promote long lasting memory responses and anti-tumor immunosurveillance. However, when each of these agents is owned by separate industries with intellectual properties, such creative combinatorial strategies may not be implemented as efficiently as we would wish. Although several early phase clinical trials demonstrated promising therapeutic outcomes to date, clinical trials of immunotherapy for gliomas have not yet demonstrated objective proof of clinical efficacy in randomized studies. The eventual success of immunotherapies for brain tumors will be dependent upon not only an in-depth understanding of immunology behind the brain and brain tumors, but also the implementation of molecularly targeted trials that address multiple layers of challenges in brain tumors.

\section{Acknowledgement}

Financial Support: the National Institute of Health 2R01NS055140, 2P01NS40923, 1P01CA132714, P3CA047904.

\section{References}

Abbott, N. J.; Ronnback, L. \& Hansson, E. (2006). Astrocyte-endothelial interactions at the blood-brain barrier, Nature Review Neuroscience, Vol. 7, No. 1, (January 2006), pp. 4153, ISSN 1471-003X

Aloisi, F. (2001). Immune function of microglia, Glia, Vol. 36, No. 2, (November 2001), pp. 165-179, ISSN 0894-1491

Andrews, D. W.; Resnicoff, M.; Flanders, A. E.; Kenyon, L.; Curtis, M.; Merli, G.; Baserga, R.; Iliakis, G. \& Aiken, R. D. (2001). Results of a pilot study involving the use of an antisense oligodeoxynucleotide directed against the insulin-like growth factor type I receptor in malignant astrocytomas, Journal of Clinical Oncology, Vol. 19, No. 8, (April 2001), pp. 2189-2200, ISSN 0732-183X

Ardon, H.; Van Gool, S.; Lopes, I. S.; Maes, W.; Sciot, R.; Wilms, G.; Demaerel, P.; Bijttebier, P.; Claes, L.; Goffin, J.; Van Calenbergh, F. \& De Vleeschouwer, S. (2010). Integration of autologous dendritic cell-based immunotherapy in the primary treatment for patients with newly diagnosed glioblastoma multiforme: a pilot study, Journal of Neuro-Oncology, Vol. 99, No. 2, (September 2010), pp. 261-272, ISSN 0167-594X

Badie, B. \& Schartner, J. M. (2000). Flow cytometric characterization of tumor-associated macrophages in experimental gliomas, Neurosurgery, Vol. 46, No. 4, (April 2000), pp. 957-961; discussion 961-952, ISSN 0148-396X 
Banchereau, J.; Briere, F.; Caux, C.; Davoust, J.; Lebecque, S.; Liu, Y. J.; Pulendran, B. \& Palucka, K. (2000). Immunobiology of dendritic cells, Annual Review of Immunology, Vol. 18, (June 2000), pp. 767-811, ISSN 0732-0582

Barami, K. (2010). Oncomodulatory mechanisms of human cytomegalovirus in gliomas, Journal of Clinical Neuroscience, Vol. 17, No. 7, (July 2010), pp. 819-823, ISSN 09675868

Bettinger, I.; Thanos, S. \& Paulus, W. (2002). Microglia promote glioma migration, Acta Neuropathologica, Vol. 103, No. 4, (April 2002), pp. 351-355, ISSN 0001-6322

Blanc-Brude, O. P.; Yu, J.; Simosa, H.; Conte, M. S.; Sessa, W. C. \& Altieri, D. C. (2002). Inhibitor of apoptosis protein survivin regulates vascular injury, Nature Medicine, Vol. 8, No. 9, (September 2002), pp. 987-994, ISSN 1078-8956

Cartellieri, M.; Bachmann, M.; Feldmann, A.; Bippes, C.; Stamova, S.; Wehner, R.; Temme, A. \& Schmitz, M. (2010). Chimeric antigen receptor-engineered T cells for immunotherapy of cancer, Journal of Biomedicine E Biotechnology, Vol. 2010, (May 2010), pp. 956304, ISSN 1110-7243

Caruso, D. A.; Orme, L. M.; Neale, A. M.; Radcliff, F. J.; Amor, G. M.; Maixner, W.; Downie, P.; Hassall, T. E.; Tang, M. L. \& Ashley, D. M. (2004). Results of a phase 1 study utilizing monocyte-derived dendritic cells pulsed with tumor RNA in children and young adults with brain cancer, Neuro-Oncology, Vol. 6, No. 3, (July 2004), pp. 236246, ISSN 1522-8517

Castelli, M. G.; Chiabrando, C.; Fanelli, R.; Martelli, L.; Butti, G.; Gaetani, P. \& Paoletti, P. (1989). Prostaglandin and thromboxane synthesis by human intracranial tumors, Cancer Research, Vol. 49, No. 6, (March 1989), pp. 1505-1508, ISSN 0008-5472

Chen, L. (2004). Co-inhibitory molecules of the B7-CD28 family in the control of T-cell immunity, Nature Reviews Immunology, Vol. 4, No. 5, (May 2004), pp. 336-347, ISSN 1474-1733

Clavreul, A.; Piard, N.; Tanguy, J. Y.; Gamelin, E.; Rousselet, M. C.; Leynia, P. \& Menei, P. (2010). Autologous tumor cell vaccination plus infusion of GM-CSF by a programmable pump in the treatment of recurrent malignant gliomas, Journal of Clinical Neuroscience, Vol. 17, No. 7, (July 2010), pp. 842-848, ISSN 0967-5868

Cobbs, C. S.; Harkins, L.; Samanta, M.; Gillespie, G. Y.; Bharara, S.; King, P. H.; Nabors, L. B.; Cobbs, C. G. \& Britt, W. J. (2002). Human cytomegalovirus infection and expression in human malignant glioma, Cancer Research, Vol. 62, No. 12, (June 2002), pp. 33473350, ISSN 0008-5472

De Vleeschouwer, S.; Van Calenbergh, F.; Demaerel, P.; Flamen, P.; Rutkowski, S.; Kaempgen, E.; Wolff, J. E.; Plets, C.; Sciot, R. \& Van Gool, S. W. (2004). Transient local response and persistent tumor control in a child with recurrent malignant glioma: treatment with combination therapy including dendritic cell therapy. Case report, Journal of Neurosurgery, Vol. 100, No. 5, (May 2004), pp. 492-497, ISSN 0022-3085

de Vos, A. F.; van Meurs, M.; Brok, H. P.; Boven, L. A.; Hintzen, R. Q.; van der Valk, P.; Ravid, R.; Rensing, S.; Boon, L.; t Hart, B. A. \& Laman, J. D. (2002). Transfer of central nervous system autoantigens and presentation in secondary lymphoid organs, Journal of Clinical Oncology, Vol. 169, No. 10, (November 2002), pp. 54155423, ISSN 0022-1767

Debinski, W.; Gibo, D. M.; Hulet, S. W.; Connor, J. R. \& Gillespie, G. Y. (1999). Receptor for interleukin 13 is a marker and therapeutic target for human high-grade gliomas, Clinical Cancer Research, Vol. 5, No. 5, (May 1999), pp. 985-990, ISSN 1078-0432 
Desbaillets, I.; Tada, M.; de Tribolet, N.; Diserens, A. C.; Hamou, M. F. \& Van Meir, E. G. (1994). Human astrocytomas and glioblastomas express monocyte chemoattractant protein-1 (MCP-1) in vivo and in vitro, International Journal of Cancer, Vol. 58, No. 2, (July 1994), pp. 240-247, ISSN 0020-7136

Dodelet, V. C. \& Pasquale, E. B. (2000). Eph receptors and ephrin ligands: embryogenesis to tumorigenesis, Oncogene, Vol. 19, No. 49, (November 2000), pp. 5614-5619, ISSN 0950-9232

Dreno, B.; Nguyen, J. M.; Khammari, A.; Pandolfino, M. C.; Tessier, M. H.; Bercegeay, S.; Cassidanius, A.; Lemarre, P.; Billaudel, S.; Labarriere, N. \& Jotereau, F. (2002). Randomized trial of adoptive transfer of melanoma tumor-infiltrating lymphocytes as adjuvant therapy for stage III melanoma, Cancer Immunology Immunotherapy, Vol. 51, No. 10, (November 2002), pp. 539-546, ISSN 0340-7004

Dudley, M. E.; Wunderlich, J. R.; Yang, J. C.; Sherry, R. M.; Topalian, S. L.; Restifo, N. P.; Royal, R. E.; Kammula, U.; White, D. E.; Mavroukakis, S. A.; Rogers, L. J.; Gracia, G. J.; Jones, S. A.; Mangiameli, D. P.; Pelletier, M. M.; Gea-Banacloche, J.; Robinson, M. R.; Berman, D. M.; Filie, A. C.; Abati, A. \& Rosenberg, S. A. (2005). Adoptive cell transfer therapy following non-myeloablative but lymphodepleting chemotherapy for the treatment of patients with refractory metastatic melanoma, Journal of Clinical Oncology, Vol. 23, No. 10, (April 2005), pp. 2346-2357, ISSN 0732-183X

Dunn, G. P.; Dunn, I. F. \& Curry, W. T. (2007). Focus on TILs: Prognostic significance of tumor infiltrating lymphocytes in human glioma, Cancer Immunity, Vol. 7, (August 2007), pp. 12, ISSN 1424-9634

Eguchi, J.; Hatano, M.; Nishimura, F.; Zhu, X.; Dusak, J. E.; Sato, H.; Pollack, I. F.; Storkus, W. J. \& Okada, H. (2006). Identification of interleukin-13 receptor $\alpha 2$ peptide analogues capable of inducing improved antiglioma CTL responses, Cancer Research, Vol. 66, No. 11, (June 2006), pp. 5883-5891, ISSN 0008-5472

Engelhardt, B. (2008). The blood-central nervous system barriers actively control immune cell entry into the central nervous system, Current Pharmaceutical Design, Vol. 14, No. 16, (August 2008), pp. 1555-1565, ISSN 1381-6128

Fecci, P. E.; Mitchell, D. A.; Whitesides, J. F.; Xie, W.; Friedman, A. H.; Archer, G. E.; Herndon, J. E., 2nd; Bigner, D. D.; Dranoff, G. \& Sampson, J. H. (2006). Increased regulatory T-cell fraction amidst a diminished CD4 compartment explains cellular immune defects in patients with malignant glioma, Cancer Research, Vol. 66, No. 6, (March 2006), pp. 3294-3302, ISSN 0008-5472

Fujita, M.; Zhu, X.; Sasaki, K.; Ueda, R.; Low, K. L.; Pollack, I. F. \& Okada, H. (2008). Inhibition of STAT3 promotes the efficacy of adoptive transfer therapy using type-1 CTLs by modulation of the immunological microenvironment in a murine intracranial glioma, Journal of Immunology, Vol. 180, No. 4, (February 2008), pp. 2089-2098, ISSN 0022-1767

Fujita, M.; Zhu, X.; Ueda, R.; Sasaki, K.; Kohanbash, G.; Kastenhuber, E. R.; McDonald, H. A.; Gibson, G. A.; Watkins, S. C.; Muthuswamy, R.; Kalinski, P. \& Okada, H. (2009). Effective immunotherapy against murine gliomas using type 1 polarizing dendritic cells-significant roles of CXCL10, Cancer Research, Vol. 69, No. 4, (February 2009), pp. 1587-1595, ISSN 0008-5472

Fujita, M.; Scheurer, M. E.; Decker, S. A.; McDonald, H. A.; Kohanbash, G.; Kastenhuber, E. R.; Kato, H.; Bondy, M. L.; Ohlfest, J. R. \& Okada, H. (2010). Role of type 1 IFNs in antiglioma immunosurveillance-using mouse studies to guide examination of novel 
prognostic markers in humans, Clinical Cancer Research, Vol. 16, No. 13, (July 2010), pp. 3409-3419, ISSN 1078-0432

Fujita, M.; Kohanbash, G.; Fellows-Mayle, W.; Hamilton, R. L.; Komohara, Y.; Decker, S. A.; Ohlfest, J. R. \& Okada, H. (2011). COX-2 blockade suppresses gliomagenesis by inhibiting myeloid-derived suppressor cells, Cancer Research, Vol. 71, No. 7, (April 2011), pp. 2664-2667, ISSN 0008-5472

Gangemi, R. M.; Griffero, F.; Marubbi, D.; Perera, M.; Capra, M. C.; Malatesta, P.; Ravetti, G. L.; Zona, G. L.; Daga, A. \& Corte, G. (2009). SOX2 silencing in glioblastoma tumorinitiating cells causes stop of proliferation and loss of tumorigenicity, Stem Cells, Vol. 27, No. 1, (January 2009), pp. 40-48, ISSN 1066-5099

Gattinoni, L.; Powell, D. J., Jr.; Rosenberg, S. A. \& Restifo, N. P. (2006). Adoptive immunotherapy for cancer: building on success, Nature Reviews Immunology, Vol. 6, No. 5, (May 2006), pp. 383-393, ISSN 1474-1733

Glienke, W.; Maute, L.; Koehl, U.; Esser, R.; Milz, E. \& Bergmann, L. (2007). Effective treatment of leukemic cell lines with wt1 siRNA, Leukemia, Vol. 21, No. 10, (October 2007), pp. 2164-2170, ISSN 0887-6924

Gomez, G. G. \& Kruse, C. A. (2007). Cellular and functional characterization of immunoresistant human glioma cell clones selected with alloreactive cytotoxic $\mathrm{T}$ lymphocytes reveals their up-regulated synthesis of biologically active TGF- $\beta$, Journal of Immunotherapy, Vol. 30, No. 3, (April 2007), pp. 261-273, ISSN 1524-9557

Gorelik, L. \& Flavell, R. A. (2002). Transforming growth factor-beta in T-cell biology, Nature Reviews Immunology, Vol. 2, No. 1, (January 2002), pp. 46-53, ISSN 1474-1733

Graeber, M. B.; Scheithauer, B. W. \& Kreutzberg, G. W. (2002). Microglia in brain tumors, Glia, Vol. 40, No. 2, (November 2002), pp. 252-259, ISSN 0894-1491

Grauer, O. M.; Nierkens, S.; Bennink, E.; Toonen, L. W.; Boon, L.; Wesseling, P.; Sutmuller, R. P. \& Adema, G. J. (2007). CD4+FoxP3+ regulatory T cells gradually accumulate in gliomas during tumor growth and efficiently suppress antiglioma immune responses in vivo, International Journal of Cancer, Vol. 121, No. 1, (July 2007), pp. 95105, ISSN 0020-7136

Gross, G.; Waks, T. \& Eshhar, Z. (1989). Expression of immunoglobulin-T-cell receptor chimeric molecules as functional receptors with antibody-type specificity, Proceedings of the National Academy of Sciences of the United States of America, Vol. 86, No. 24, (December 1989), pp. 10024-10028, ISSN 0027-8424

Hatano, M.; Eguchi, J.; Tatsumi, T.; Kuwashima, N.; Dusak, J. E.; Kinch, M. S.; Pollack, I. F.; Hamilton, R. L.; Storkus, W. J. \& Okada, H. (2005). EphA2 as a glioma-associated antigen: a novel target for glioma vaccines, Neoplasia, Vol. 7, No. 8, (August 2005), pp. 717-722, ISSN 1522-8002

Heimberger, A. B.; Abou-Ghazal, M.; Reina-Ortiz, C.; Yang, D. S.; Sun, W.; Qiao, W.; Hiraoka, N. \& Fuller, G. N. (2008). Incidence and prognostic impact of FoxP3+ regulatory $\mathrm{T}$ cells in human gliomas, Clinical Cancer Research, Vol. 14, No. 16, (August 2008), pp. 5166-5172, ISSN 1078-0432

Holladay, F. P.; Heitz-Turner, T.; Bayer, W. L. \& Wood, G. W. (1996). Autologous tumor cell vaccination combined with adoptive cellular immunotherapy in patients with grade III/IV astrocytoma, Journal of Neuro-Oncology, Vol. 27, No. 2, (February 1996), pp. 179-189, ISSN 0167-594X

Huang, B.; Lei, Z.; Zhao, J.; Gong, W.; Liu, J.; Chen, Z.; Liu, Y.; Li, D.; Yuan, Y.; Zhang, G. M. \& Feng, Z. H. (2007). CCL2/CCR2 pathway mediates recruitment of myeloid 
suppressor cells to cancers, Cancer Letters, Vol. 252, No. 1, (July 2007), pp. 86-92, ISSN 0304-3835

Huettner, C.; Czub, S.; Kerkau, S.; Roggendorf, W. \& Tonn, J. C. (1997). Interleukin 10 is expressed in human gliomas in vivo and increases glioma cell proliferation and motility in vitro, Anticancer Research, Vol. 17, No. 5A, (September 1997), pp. 32173224, ISSN 0250-7005

Hussain, S. F.; Yang, D.; Suki, D.; Aldape, K.; Grimm, E. \& Heimberger, A. B. (2006). The role of human glioma-infiltrating microglia/macrophages in mediating antitumor immune responses, Neuro-Oncology, Vol. 8, No. 3, (July 2006), pp. 261-279, ISSN 1522-8517

Ishikawa, E.; Tsuboi, K.; Yamamoto, T.; Muroi, A.; Takano, S.; Enomoto, T.; Matsumura, A. \& Ohno, T. (2007). Clinical trial of autologous formalin-fixed tumor vaccine for glioblastoma multiforme patients, Cancer Science, Vol. 98, No. 8, (August 2007), pp. 1226-1233, ISSN 1347-9032

Izumoto, S.; Tsuboi, A.; Oka, Y.; Suzuki, T.; Hashiba, T.; Kagawa, N.; Hashimoto, N.; Maruno, M.; Elisseeva, O. A.; Shirakata, T.; Kawakami, M.; Oji, Y.; Nishida, S.; Ohno, S.; Kawase, I.; Hatazawa, J.; Nakatsuka, S.; Aozasa, K.; Morita, S.; Sakamoto, J.; Sugiyama, H. \& Yoshimine, T. (2008). Phase II clinical trial of Wilms tumor 1 peptide vaccination for patients with recurrent glioblastoma multiforme, Journal of Neurosurgery, Vol. 108, No. 5, (May 2008), pp. 963-971, ISSN 0022-3085

Jordan, J. T.; Sun, W.; Hussain, S. F.; DeAngulo, G.; Prabhu, S. S. \& Heimberger, A. B. (2008). Preferential migration of regulatory $\mathrm{T}$ cells mediated by glioma-secreted chemokines can be blocked with chemotherapy, Cancer Immunology Immunotherapy, Vol. 57, No. 1, (January 2008), pp. 123-131, ISSN 0340-7004

Kahlon, K. S.; Brown, C.; Cooper, L. J.; Raubitschek, A.; Forman, S. J. \& Jensen, M. C. (2004). Specific recognition and killing of glioblastoma multiforme by interleukin 13zetakine redirected cytolytic T cells, Cancer Research, Vol. 64, No. 24, (December 2004), pp. 9160-9166, ISSN 0008-5472

Kantoff, P. W.; Higano, C. S.; Shore, N. D.; Berger, E. R.; Small, E. J.; Penson, D. F.; Redfern, C. H.; Ferrari, A. C.; Dreicer, R.; Sims, R. B.; Xu, Y.; Frohlich, M. W. \& Schellhammer, P. F. (2010). Sipuleucel-T immunotherapy for castration-resistant prostate cancer, New England Journal of Medicine, Vol. 363, No. 5, (July 2010), pp. 411-422, ISSN 1533-4406

Kikuchi, T.; Akasaki, Y.; Irie, M.; Homma, S.; Abe, T. \& Ohno, T. (2001). Results of a phase I clinical trial of vaccination of glioma patients with fusions of dendritic and glioma cells, Cancer Immunology Immunotherapy, Vol. 50, No. 7, (September 2001), pp. 337344, ISSN 0340-7004

Kikuchi, T.; Akasaki, Y.; Abe, T.; Fukuda, T.; Saotome, H.; Ryan, J. L.; Kufe, D. W. \& Ohno, T. (2004). Vaccination of glioma patients with fusions of dendritic and glioma cells and recombinant human interleukin 12, Journal of Immunotherapy, Vol. 27, No. 6, (November 2004), pp. 452-459, ISSN 1524-9557

Kuwashima, N.; Nishimura, F.; Eguchi, J.; Sato, H.; Hatano, M.; Tsugawa, T.; Sakaida, T.; Dusak, J. E.; Fellows-Mayle, W. K.; Papworth, G. D.; Watkins, S. C.; Gambotto, A.; Pollack, I. F.; Storkus, W. J. \& Okada, H. (2005). Delivery of dendritic cells engineered to secrete IFN- $\alpha$ into central nervous system tumors enhances the efficacy of peripheral tumor cell vaccines: dependence on apoptotic pathways, Journal of Immunology, Vol. 175, No. 4, (August 2005), pp. 2730-2740, ISSN 0022-1767

Li, Y.; Moysey, R.; Molloy, P. E.; Vuidepot, A. L.; Mahon, T.; Baston, E.; Dunn, S.; Liddy, N.; Jacob, J.; Jakobsen, B. K. \& Boulter, J. M. (2005). Directed evolution of human T-cell 
receptors with picomolar affinities by phage display, Nature Biotechnology, Vol. 23, No. 3, (March 2005), pp. 349-354, ISSN 1087-0156

Liau, L. M.; Prins, R. M.; Kiertscher, S. M.; Odesa, S. K.; Kremen, T. J.; Giovannone, A. J.; Lin, J. W.; Chute, D. J.; Mischel, P. S.; Cloughesy, T. F. \& Roth, M. D. (2005). Dendritic cell vaccination in glioblastoma patients induces systemic and intracranial T-cell responses modulated by the local central nervous system tumor microenvironment, Clinical Cancer Research, Vol. 11, No. 15, (August 2005), pp. 5515-5525, ISSN 1078-0432

Liu, F.; Park, P. J.; Lai, W.; Maher, E.; Chakravarti, A.; Durso, L.; Jiang, X.; Yu, Y.; Brosius, A.; Thomas, M.; Chin, L.; Brennan, C.; DePinho, R. A.; Kohane, I.; Carroll, R. S.; Black, P. M. \& Johnson, M. D. (2006). A genome-wide screen reveals functional gene clusters in the cancer genome and identifies EphA2 as a mitogen in glioblastoma, Cancer Research, Vol. 66, No. 22, (November 2006), pp. 10815-10823, ISSN 0008-5472

Lucas, K. G.; Bao, L.; Bruggeman, R.; Dunham, K. \& Specht, C. (2010). The detection of CMV pp65 and IE1 in glioblastoma multiforme, Journal of Neuro-Oncology, Vol. 103, No. 2, (September 2010), pp. 231-238, ISSN 0167-594X

Mitchell, D. A.; Xie, W.; Schmittling, R.; Learn, C.; Friedman, A.; McLendon, R. E. \& Sampson, J. H. (2008). Sensitive detection of human cytomegalovirus in tumors and peripheral blood of patients diagnosed with glioblastoma, Neuro-Oncology, Vol. 10, No. 1, (February 2008), pp. 10-18, ISSN 1522-8517

Moore, K. W.; de Waal Malefyt, R.; Coffman, R. L. \& O'Garra, A. (2001). Interleukin-10 and the interleukin-10 receptor, Annual Review of Immunology, Vol. 19, (March 2001), pp. 683-765, ISSN 0732-0582

Morgan, R. A.; Dudley, M. E.; Wunderlich, J. R.; Hughes, M. S.; Yang, J. C.; Sherry, R. M.; Royal, R. E.; Topalian, S. L.; Kammula, U. S.; Restifo, N. P.; Zheng, Z.; Nahvi, A.; de Vries, C. R.; Rogers-Freezer, L. J.; Mavroukakis, S. A. \& Rosenberg, S. A. (2006). Cancer regression in patients after transfer of genetically engineered lymphocytes, Science, Vol. 314, No. 5796, (October 2006), pp. 126-129, ISSN 0036-8075

Nishimura, F.; Dusak, J. E.; Eguchi, J.; Zhu, X.; Gambotto, A.; Storkus, W. J. \& Okada, H. (2006). Adoptive transfer of type 1 CTL mediates effective anti-central nervous system tumor response: critical roles of IFN-inducible protein-10, Cancer Research, Vol. 66, No. 8, (April 2006), pp. 4478-4487, ISSN 0008-5472

Nitta, T.; Hishii, M.; Sato, K. \& Okumura, K. (1994). Selective expression of interleukin-10 gene within glioblastoma multiforme, Brain Research, Vol. 649, No. 1-2, (June 1994), pp. 122-128, ISSN 0006-8993

Ohno, M.; Natsume, A.; Ichiro Iwami, K.; Iwamizu, H.; Noritake, K.; Ito, D.; Toi, Y.; Ito, M.; Motomura, K.; Yoshida, J.; Yoshikawa, K. \& Wakabayashi, T. (2010). Retrovirally engineered T-cell-based immunotherapy targeting type III variant epidermal growth factor receptor, a glioma-associated antigen, Cancer Science, Vol. 101, No. 12, (December 2010), pp. 2518-2524, ISSN 1347-9032

Oka, Y.; Tsuboi, A.; Elisseeva, O. A.; Udaka, K. \& Sugiyama, H. (2002). WT1 as a novel target antigen for cancer immunotherapy, Current Cancer Drug Targets, Vol. 2, No. 1, (March 2002), pp. 45-54, ISSN 1568-0096

Okada, H.; Lieberman, F. S.; Walter, K. A.; Lunsford, L. D.; Kondziolka, D. S.; Bejjani, G. K.; Hamilton, R. L.; Torres-Trejo, A.; Kalinski, P.; Cai, Q.; Mabold, J. L.; Edington, H. D.; Butterfield, L. H.; Whiteside, T. L.; Potter, D. M.; Schold, S. C., Jr. \& Pollack, I. F. (2007). Autologous glioma cell vaccine admixed with interleukin-4 gene transfected fibroblasts in the treatment of patients with malignant gliomas, Journal of Translational Medicien, Vol. 5, (December 2007), pp. 67, ISSN 1479-5876 
Okada, H.; Kohanbash, G.; Zhu, X.; Kastenhuber, E. R.; Hoji, A.; Ueda, R. \& Fujita, M. (2009). Immunotherapeutic approaches for glioma, Critical Reviews in Immunology, Vol. 29, No. 1, (April 2009), pp. 1-42, ISSN 1040-8401

Okada, H.; Kalinski, P.; Ueda, R.; Hoji, A.; Kohanbash, G.; Donegan, T. E.; Mintz, A. H.; Engh, J. A.; Bartlett, D. L.; Brown, C. K.; Zeh, H.; Holtzman, M. P.; Reinhart, T. A.; Whiteside, T. L.; Butterfield, L. H.; Hamilton, R. L.; Potter, D. M.; Pollack, I. F.; Salazar, A. M. \& Lieberman, F. S. (2011). Induction of CD8+ T-cell responses against novel glioma-associated antigen peptides and clinical activity by vaccinations with $\alpha$ type 1 polarized dendritic cells and polyinosinic-polycytidylic acid stabilized by lysine and carboxymethylcellulose in patients with recurrent malignant glioma, Journal of Clinical Oncology, Vol. 29, No. 3, (January 2011), pp. 330-336, ISSN 0732-183X

Okada, N.; Mori, N.; Koretomo, R.; Okada, Y.; Nakayama, T.; Yoshie, O.; Mizuguchi, H.; Hayakawa, T.; Nakagawa, S.; Mayumi, T.; Fujita, T. \& Yamamoto, A. (2005). Augmentation of the migratory ability of DC-based vaccine into regional lymph nodes by efficient CCR7 gene transduction, Gene Therapy, Vol. 12, No. 2, (January 2005), pp. 129-139, ISSN 0969-7128

Parney, I. F.; Chang, L. J.; Farr-Jones, M. A.; Hao, C.; Smylie, M. \& Petruk, K. C. (2006). Technical hurdles in a pilot clinical trial of combined B7-2 and GM-CSF immunogene therapy for glioblastomas and melanomas, Journal of Neuro-Oncology, Vol. 78, No. 1, (May 2006), pp. 71-80, ISSN 0167-594X

Parsa, A. T.; Waldron, J. S.; Panner, A.; Crane, C. A.; Parney, I. F.; Barry, J. J.; Cachola, K. E.; Murray, J. C.; Tihan, T.; Jensen, M. C.; Mischel, P. S.; Stokoe, D. \& Pieper, R. O. (2007). Loss of tumor suppressor PTEN function increases B7-H1 expression and immunoresistance in glioma, Nature Medicine, Vol. 13, No. 1, (January 2007), pp. 8488, ISSN 1078-8956

Perret, R. \& Ronchese, F. (2008). Memory T cells in cancer immunotherapy: which CD8 Tcell population provides the best protection against tumours?, Tissue Antigens, Vol. 72, No. 3, (September 2008), pp. 187-194, ISSN 0001-2815

Plautz, G. E.; Barnett, G. H.; Miller, D. W.; Cohen, B. H.; Prayson, R. A.; Krauss, J. C.; Luciano, M.; Kangisser, D. B. \& Shu, S. (1998). Systemic T cell adoptive immunotherapy of malignant gliomas, Journal of Neurosurgery, Vol. 89, No. 1, (July 1998), pp. 42-51, ISSN 0022-3085

Plautz, G. E.; Miller, D. W.; Barnett, G. H.; Stevens, G. H.; Maffett, S.; Kim, J.; Cohen, P. A. \& Shu, S. (2000). T cell adoptive immunotherapy of newly diagnosed gliomas, Clinical Cancer Research, Vol. 6, No. 6, (June 2000), pp. 2209-2218, ISSN 1078-0432

Prins, R. M.; Soto, H.; Konkankit, V.; Odesa, S. K.; Eskin, A.; Yong, W. H.; Nelson, S. F. \& Liau, L. M. (2011). Gene expression profile correlates with T-cell infiltration and relative survival in glioblastoma patients vaccinated with dendritic cell immunotherapy, Clinical Cancer Research, Vol. 17, No. 6, (March 2011), pp. 1603-1615, ISSN 1078-0432

Ransohoff, R. M.; Kivisakk, P. \& Kidd, G. (2003). Three or more routes for leukocyte migration into the central nervous system, Nature Reviews Immunology, Vol. 3, No. 7, (July 2003), pp. 569-581, ISSN 1474-1733

Robbins, P. F.; Dudley, M. E.; Wunderlich, J.; El-Gamil, M.; Li, Y. F.; Zhou, J.; Huang, J.; Powell, D. J., Jr. \& Rosenberg, S. A. (2004). Cutting edge: persistence of transferred lymphocyte clonotypes correlates with cancer regression in patients receiving cell transfer therapy, Journal of Immunology, Vol. 173, No. 12, (December 2004), pp. 71257130, ISSN 0022-1767 
Rosenberg, S. A. (2008). Overcoming obstacles to the effective immunotherapy of human cancer, Proceedings of the National Academy of Sciences of the United States of America, Vol. 105, No. 35, (September 2008), pp. 12643-12644, ISSN 0027-8424

Rushing, E. J.; Sandberg, G. D. \& Horkayne-Szakaly, I. (2010). High-grade astrocytomas show increased Nestin and Wilms's tumor gene (WT1) protein expression, International Journal of Surgical Pathology, Vol. 18, No. 4, (August 2010), pp. 255-259, ISSN 1066-8969

Rutkowski, S.; De Vleeschouwer, S.; Kaempgen, E.; Wolff, J. E.; Kuhl, J.; Demaerel, P.; Warmuth-Metz, M.; Flamen, P.; Van Calenbergh, F.; Plets, C.; Sorensen, N.; Opitz, A. \& Van Gool, S. W. (2004). Surgery and adjuvant dendritic cell-based tumour vaccination for patients with relapsed malignant glioma, a feasibility study, British Journal of Cancer, Vol. 91, No. 9, (November 2004), pp. 1656-1662, ISSN 0007-0920

Saikali, S.; Avril, T.; Collet, B.; Hamlat, A.; Bansard, J. Y.; Drenou, B.; Guegan, Y. \& Quillien, V. (2007). Expression of nine tumour antigens in a series of human glioblastoma multiforme: interest of EGFRvIII, IL-13Ro2, gp100 and TRP-2 for immunotherapy, Journal of Neuro-Oncology, Vol. 81, No. 2, (January 2007), pp. 139-148, ISSN 0167-594X

Salcedo, R.; Ponce, M. L.; Young, H. A.; Wasserman, K.; Ward, J. M.; Kleinman, H. K.; Oppenheim, J. J. \& Murphy, W. J. (2000). Human endothelial cells express CCR2 and respond to $\mathrm{MCP}-1$ : direct role of $\mathrm{MCP}-1$ in angiogenesis and tumor progression, Blood, Vol. 96, No. 1, (July 2000), pp. 34-40, ISSN 0006-4971

Sampson, J. H.; Archer, G. E.; Mitchell, D. A.; Heimberger, A. B.; Herndon, J. E., 2nd; LallyGoss, D.; McGehee-Norman, S.; Paolino, A.; Reardon, D. A.; Friedman, A. H.; Friedman, H. S. \& Bigner, D. D. (2009). An epidermal growth factor receptor variant III-targeted vaccine is safe and immunogenic in patients with glioblastoma multiforme, Molecular Cancer Therapy, Vol. 8, No. 10, (October 2009), pp. 2773-2779, ISSN 1535-7163

Sampson, J. H.; Heimberger, A. B.; Archer, G. E.; Aldape, K. D.; Friedman, A. H.; Friedman, H. S.; Gilbert, M. R.; Herndon, J. E., 2nd; McLendon, R. E.; Mitchell, D. A.; Reardon, D. A.; Sawaya, R.; Schmittling, R. J.; Shi, W.; Vredenburgh, J. J. \& Bigner, D. D. (2010). Immunologic escape after prolonged progression-free survival with epidermal growth factor receptor variant III peptide vaccination in patients with newly diagnosed glioblastoma, Journal of Clinical Oncology, Vol. 28, No. 31, (November 2010), pp. 4722-4729, ISSN 0732-183X

Sasaki, K.; Zhu, X.; Vasquez, C.; Nishimura, F.; Dusak, J. E.; Huang, J.; Fujita, M.; Wesa, A.; Potter, D. M.; Walker, P. R.; Storkus, W. J. \& Okada, H. (2007). Preferential expression of very late antigen- 4 on type 1 CTL cells plays a critical role in trafficking into central nervous system tumors, Cancer Research, Vol. 67, No. 13, (July 2007), pp. 6451-6458, ISSN 0008-5472

Sasaki, K.; Pardee, A. D.; Okada, H. \& Storkus, W. J. (2008a). IL-4 inhibits VLA-4 expression on Tc1 cells resulting in poor tumor infiltration and reduced therapy benefit, European Journal of Immunology, Vol. 38, No. 10, (October 2008), pp. 2865-2873, ISSN 0014-2980

Sasaki, K.; Zhao, X.; Pardee, A. D.; Ueda, R.; Fujita, M.; Sehra, S.; Kaplan, M. H.; Kane, L. P.; Okada, H. \& Storkus, W. J. (2008b). Stat6 signaling suppresses VLA-4 expression by CD8+ T cells and limits their ability to infiltrate tumor lesions in vivo, Journal of Immunology, Vol. 181, No. 1, (July 2008), pp. 104-108, ISSN 0022-1767

Sasaki, K.; Pardee, A. D.; Qu, Y.; Zhao, X.; Ueda, R.; Kohanbash, G.; Bailey, L. M.; Okada, H.; Muthuswamy, R.; Kalinski, P.; Basse, P. H.; Falo, L. D. \& Storkus, W. J. (2009). IL-4 
suppresses very late antigen-4 expression which is required for therapeutic Th1 Tcell trafficking into tumors, Journal of Immunotherapy, Vol. 32, No. 8, (October 2009), pp. 793-802, ISSN 1524-9557

Scheurer, M. E.; Bondy, M. L.; Aldape, K. D.; Albrecht, T. \& El-Zein, R. (2008). Detection of human cytomegalovirus in different histological types of gliomas, Acta Neuropathologica, Vol. 116, No. 1, (July 2008), pp. 79-86, ISSN 0001-6322

Schittenhelm, J.; Mittelbronn, M.; Nguyen, T. D.; Meyermann, R. \& Beschorner, R. (2008). WT1 expression distinguishes astrocytic tumor cells from normal and reactive astrocytes, Brain Pathology, Vol. 18, No. 3, (July 2008), pp. 344-353, ISSN 1015-6305

Schmitz, M.; Wehner, R.; Stevanovic, S.; Kiessling, A.; Rieger, M. A.; Temme, A.; Bachmann, M.; Rieber, E. P. \& Weigle, B. (2007). Identification of a naturally processed T cell epitope derived from the glioma-associated protein SOX11, Cancer Letters, Vol. 245, No. 1-2, (January 2007), pp. 331-336, ISSN 0304-3835

Schneider, T.; Gerhards, R.; Kirches, E. \& Firsching, R. (2001). Preliminary results of active specific immunization with modified tumor cell vaccine in glioblastoma multiforme, Journal of Neuro-Oncology, Vol. 53, No. 1, (May 2001), pp. 39-46, ISSN 0167-594X

Shinohara, H.; Yagita, H.; Ikawa, Y. \& Oyaizu, N. (2000). Fas drives cell cycle progression in glioma cells via extracellular signal-regulated kinase activation, Cancer Research, Vol. 60, No. 6, (March 2000), pp. 1766-1772, ISSN 0008-5472

Sloan, A. E.; Dansey, R.; Zamorano, L.; Barger, G.; Hamm, C.; Diaz, F.; Baynes, R. \& Wood, G. (2000). Adoptive immunotherapy in patients with recurrent malignant glioma: preliminary results of using autologous whole-tumor vaccine plus granulocytemacrophage colony-stimulating factor and adoptive transfer of anti-CD3-activated lymphocytes, Neurosurgical Focus, Vol. 9, No. 6, (July 2000), pp. e9, ISSN 1092-0684

Steiner, H. H.; Bonsanto, M. M.; Beckhove, P.; Brysch, M.; Geletneky, K.; Ahmadi, R.; Schuele-Freyer, R.; Kremer, P.; Ranaie, G.; Matejic, D.; Bauer, H.; Kiessling, M.; Kunze, S.; Schirrmacher, V. \& Herold-Mende, C. (2004). Antitumor vaccination of patients with glioblastoma multiforme: a pilot study to assess feasibility, safety, and clinical benefit, Journal of Clinical Oncology, Vol. 22, No. 21, (November 2004), pp. 4272-4281, ISSN 0732-183X

Takeshima, H.; Kuratsu, J.; Takeya, M.; Yoshimura, T. \& Ushio, Y. (1994). Expression and localization of messenger RNA and protein for monocyte chemoattractant protein-1 in human malignant glioma, Journal of Neurosurgery, Vol. 80, No. 6, (June 1994), pp. 1056-1062, ISSN 0022-3085

Terasaki, M.; Shibui, S.; Narita, Y.; Fujimaki, T.; Aoki, T.; Kajiwara, K.; Sawamura, Y.; Kurisu, K.; Mineta, T.; Yamada, A. \& Itoh, K. (2011). Phase I trial of a personalized peptide vaccine for patients positive for human leukocyte antigen -A24 with recurrent or progressive glioblastoma multiforme, Journal of Clinical Oncology, Vol. 29, No. 3, (January 2011), pp. 337-344, ISSN 0732-183X

Ueda, R.; Iizuka, Y.; Yoshida, K.; Kawase, T.; Kawakami, Y. \& Toda, M. (2004). Identification of a human glioma antigen, SOX6, recognized by patients' sera, Oncogene, Vol. 23, No. 7, (February 2004), pp. 1420-1427, ISSN 0950-9232

Ueda, R.; Yoshida, K.; Kawase, T.; Kawakami, Y. \& Toda, M. (2007). Preferential expression and frequent IgG responses of a tumor antigen, SOX5, in glioma patients, International Journal of Cancer, Vol. 120, No. 8, (April 2007), pp. 1704-1711, ISSN 0020-7136

Ueda, R.; Fujita, M.; Zhu, X.; Sasaki, K.; Kastenhuber, E. R.; Kohanbash, G.; McDonald, H. A.; Harper, J.; Lonning, S. \& Okada, H. (2009). Systemic inhibition of transforming growth factor- $\beta$ in glioma-bearing mice improves the therapeutic efficacy of 
glioma-associated antigen peptide vaccines, Clinical Cancer Research, Vol. 15, No. 21, (November 2009), pp. 6551-6559, ISSN 1078-0432

Uematsu, M.; Ohsawa, I.; Aokage, T.; Nishimaki, K.; Matsumoto, K.; Takahashi, H.; Asoh, S.; Teramoto, A. \& Ohta, S. (2005). Prognostic significance of the immunohistochemical index of survivin in glioma: a comparative study with the MIB-1 index, Journal of Neuro-Oncology, Vol. 72, No. 3, (May 2005), pp. 231-238, ISSN 0167-594X

Vanderlugt, C. L. \& Miller, S. D. (2002). Epitope spreading in immune-mediated diseases: implications for immunotherapy, Nature Reviews Immunology, Vol. 2, No. 2, (February 2002), pp. 85-95, ISSN 1474-1733

Vauleon, E.; Avril, T.; Collet, B.; Mosser, J. \& Quillien, V. (2010). Overview of cellular immunotherapy for patients with glioblastoma, Clinical \& Developmental Immunology, Vol. 2010, (October 2010), pp. 689171, ISSN 1740-2522

Walker, D. G.; Laherty, R.; Tomlinson, F. H.; Chuah, T. \& Schmidt, C. (2008). Results of a phase I dendritic cell vaccine trial for malignant astrocytoma: potential interaction with adjuvant chemotherapy, Journal of Clinical Neuroscience, Vol. 15, No. 2, (February 2008), pp. 114-121, ISSN 0967-5868

Walker, P. R.; Saas, P. \& Dietrich, P. Y. (1997). Role of Fas ligand (CD95L) in immune escape: the tumor cell strikes back, Journal of Immunology, Vol. 158, No. 10, (May 1997), pp. 4521-4524, ISSN 0022-1767

Walker, P. R.; Calzascia, T.; de Tribolet, N. \& Dietrich, P. Y. (2003). T-cell immune responses in the brain and their relevance for cerebral malignancies, Brain Research. Brain Research Reviews, Vol. 42, No. 2, (May 2003), pp. 97-122

Wang, X.; Berger, C.; Wong, C. W.; Forman, S. J.; Riddell, S. R. \& Jensen, M. C. (2011). Engraftment of human central memory-derived effector CD8+ $\mathrm{T}$ cells in immunodeficient mice, Blood, Vol. 117, No. 6, (February 2011), pp. 1888-1898, ISSN 0006-4971

Watters, J. J.; Schartner, J. M. \& Badie, B. (2005). Microglia function in brain tumors, Journal of Neuroscience Research, Vol. 81, No. 3, (August 2005), pp. 447-455, ISSN 0360-4012

Wegner, M. (1999). From head to toes: the multiple facets of Sox proteins, Nucleic Acids Research, Vol. 27, No. 6, (March 1999), pp. 1409-1420, ISSN 0305-1048

Wheeler, C. J.; Das, A.; Liu, G.; Yu, J. S. \& Black, K. L. (2004). Clinical responsiveness of glioblastoma multiforme to chemotherapy after vaccination, Clinical Cancer Research, Vol. 10, No. 16, (August 2004), pp. 5316-5326, ISSN 1078-0432

Wheeler, C. J.; Black, K. L.; Liu, G.; Mazer, M.; Zhang, X. X.; Pepkowitz, S.; Goldfinger, D.; $\mathrm{Ng}$, H.; Irvin, D. \& Yu, J. S. (2008). Vaccination elicits correlated immune and clinical responses in glioblastoma multiforme patients, Cancer Research, Vol. 68, No. 14, (July 2008), pp. 5955-5964, ISSN 0008-5472

Wherry, E. J.; Teichgraber, V.; Becker, T. C.; Masopust, D.; Kaech, S. M.; Antia, R.; von Andrian, U. H. \& Ahmed, R. (2003). Lineage relationship and protective immunity of memory CD8 T cell subsets, Nature Immunology, Vol. 4, No. 3, (March 2003), pp. 225-234, ISSN 1529-2908

Wikstrand, C. J. \& Bigner, D. D. (1980). Immunobiologic aspects of the brain and human gliomas. A review, American Journal of Pathology, Vol. 98, No. 2, (February 1980), pp. 517-568, ISSN 0002-9440

Wintterle, S.; Schreiner, B.; Mitsdoerffer, M.; Schneider, D.; Chen, L.; Meyermann, R.; Weller, M. \& Wiendl, H. (2003). Expression of the B7-related molecule B7-H1 by glioma cells: a potential mechanism of immune paralysis, Cancer Research, Vol. 63, No. 21, (November 2003), pp. 7462-7467, ISSN 0008-5472 
Wood, G. W.; Holladay, F. P.; Turner, T.; Wang, Y. Y. \& Chiga, M. (2000). A pilot study of autologous cancer cell vaccination and cellular immunotherapy using anti-CD3 stimulated lymphocytes in patients with recurrent grade III/IV astrocytoma, Journal of Neuro-Oncology, Vol. 48, No. 2, (June 2000), pp. 113-120, ISSN 0167-594X

Yajima, N.; Yamanaka, R.; Mine, T.; Tsuchiya, N.; Homma, J.; Sano, M.; Kuramoto, T.; Obata, Y.; Komatsu, N.; Arima, Y.; Yamada, A.; Shigemori, M.; Itoh, K. \& Tanaka, R. (2005). Immunologic evaluation of personalized peptide vaccination for patients with advanced malignant glioma, Clinical Cancer Research, Vol. 11, No. 16, (August 2005), pp. 5900-5911, ISSN 1078-0432

Yamanaka, R.; Abe, T.; Yajima, N.; Tsuchiya, N.; Homma, J.; Kobayashi, T.; Narita, M.; Takahashi, M. \& Tanaka, R. (2003). Vaccination of recurrent glioma patients with tumour lysate-pulsed dendritic cells elicits immune responses: results of a clinical phase I/II trial, British Journal of Cancer, Vol. 89, No. 7, (October 2003), pp. 11721179, ISSN 0007-0920

Yamanaka, R.; Homma, J.; Yajima, N.; Tsuchiya, N.; Sano, M.; Kobayashi, T.; Yoshida, S.; Abe, T.; Narita, M.; Takahashi, M. \& Tanaka, R. (2005). Clinical evaluation of dendritic cell vaccination for patients with recurrent glioma: results of a clinical phase I/II trial, Clinical Cancer Research, Vol. 11, No. 11, (June 2005), pp. 4160-4167, ISSN 1078-0432

Yang, S.; Luca, G.; Liu, F.; Ji, Y.; Yu, Z.; Restifo, N. P.; Rosenberg, S. A. \& Morgan, R. A. (2011). In vitro generated anti-tumor $\mathrm{T}$ lymphocytes exhibit distinct subsets mimicking in vivo antigen-experienced cells, Cancer Immunology Immunotherapy, Vol. 60, No. 5,(February 2011), pp. pp. 739-749 ISSN 0340-7004

Yu, J. S.; Wheeler, C. J.; Zeltzer, P. M.; Ying, H.; Finger, D. N.; Lee, P. K.; Yong, W. H.; Incardona, F.; Thompson, R. C.; Riedinger, M. S.; Zhang, W.; Prins, R. M. \& Black, K. L. (2001). Vaccination of malignant glioma patients with peptide-pulsed dendritic cells elicits systemic cytotoxicity and intracranial T-cell infiltration, Cancer Research, Vol. 61, No. 3, (February 2001), pp. 842-847, ISSN 0008-5472

Yu, J. S.; Liu, G.; Ying, H.; Yong, W. H.; Black, K. L. \& Wheeler, C. J. (2004). Vaccination with tumor lysate-pulsed dendritic cells elicits antigen-specific, cytotoxic T-cells in patients with malignant glioma, Cancer Research, Vol. 64, No. 14, (July 2004), pp. 4973-4979, ISSN 0008-5472

Zhang, J. G.; Eguchi, J.; Kruse, C. A.; Gomez, G. G.; Fakhrai, H.; Schroter, S.; Ma, W.; Hoa, N.; Minev, B.; Delgado, C.; Wepsic, H. T.; Okada, H. \& Jadus, M. R. (2007). Antigenic profiling of glioma cells to generate allogeneic vaccines or dendritic cellbased therapeutics, Clinical Cancer Research, Vol. 13, No. 2, (January 2007), pp. 566575, ISSN 1078-0432 


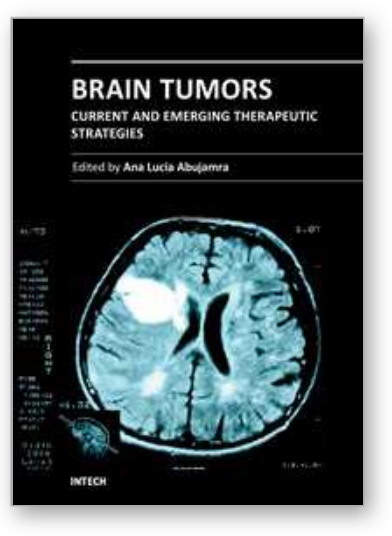

\author{
Brain Tumors - Current and Emerging Therapeutic Strategies \\ Edited by Dr. Ana Lucia Abujamra
}

ISBN 978-953-307-588-4

Hard cover, 422 pages

Publisher InTech

Published online 23, August, 2011

Published in print edition August, 2011

Brain Tumors: Current and Emerging Therapeutic Strategies focuses on tumor models, the molecular mechanisms involved in the pathogenesis of this disease, and on the new diagnostic and treatment strategies utilized to stage and treat this malignancy. A special section on immunotherapy and gene therapy provides the most up-to-date information on the pre-clinical and clinical advances of this therapeutic venue. Each chapter in Brain Tumors: Current and Emerging Therapeutic Strategies is authored by international experts with extensive experience in the areas covered.

\title{
How to reference
}

In order to correctly reference this scholarly work, feel free to copy and paste the following:

Mitsugu Fujita and Hideho Okada (2011). Immunotherapeutic Strategies for Brain Tumors, Brain Tumors Current and Emerging Therapeutic Strategies, Dr. Ana Lucia Abujamra (Ed.), ISBN: 978-953-307-588-4, InTech, Available from: http://www.intechopen.com/books/brain-tumors-current-and-emerging-therapeuticstrategies/immunotherapeutic-strategies-for-brain-tumors

\section{INTECH}

open science | open minds

\section{InTech Europe}

University Campus STeP Ri

Slavka Krautzeka 83/A

51000 Rijeka, Croatia

Phone: +385 (51) 770447

Fax: +385 (51) 686166

www.intechopen.com

\section{InTech China}

Unit 405, Office Block, Hotel Equatorial Shanghai

No.65, Yan An Road (West), Shanghai, 200040, China

中国上海市延安西路65号上海国际贵都大饭店办公楼 405 单元

Phone: +86-21-62489820

Fax: +86-21-62489821 
(C) 2011 The Author(s). Licensee IntechOpen. This chapter is distributed under the terms of the Creative Commons Attribution-NonCommercialShareAlike-3.0 License, which permits use, distribution and reproduction for non-commercial purposes, provided the original is properly cited and derivative works building on this content are distributed under the same license. 